\author{
Radosław Zenderowski \\ Uniwersytet Kardynała Stefana Wyszyńskiego \\ (D) https://orcid.org/0000-0003-0249-0499
}

\title{
Preferencje polityczne (wyborcze) Polaków zamieszkujących Zaolzie (1990-2018)
}

\begin{abstract}
The article analyses the issue of election activity of the Polish inhabitants of the Zaolzie region (the Czech Republic) in the 1990-2018 period referring to national elections (Lower Chamber of Parliament, Senate, President of the Czech Republic) as well as local and regional elections. The theoretical section offers analyses of national and ethnic minorities as (collective) political actors. The empirical part provides an in-depth analysis of the votes in particular elections, taking into consideration the communes with a significant rate of Polish inhabitants as well as those communes there the Polish ethnos was rather scarce. The ethnic affiliation has been considered as a vital independent variable of the choices made, however, other variables explaining election behaviour have also been indicated.
\end{abstract}

Key words: Zaolzie, Czech Republic, Polish national minority, elections, politics

\section{Wstęp}

W związku z rosnącym znaczeniem mniejszości narodowych i etnicznych w polityce krajowej i międzynarodowej (vide: rola dyplomacji samorządowej i obywatelskiej w regionach wielokulturowych, dyplomacja diaspor), wzrostem (samo)świadomości ich elit i członków w zakresie przysługujących im praw, ale i możliwości oddziaływania politycznego, a także rozwojem badań z zakresu nauk politycznych nad zachowaniami wyborczymi mniejszości narodowych, etnicznych i religijnych — interesująca badawczo okazała się zapomniana 
i „zaniedbana naukowo” na gruncie nauk o polityce polska mniejszość narodowa na Zaolziu'.

Teren Zaolzia w odniesieniu do kwestii polskiej rozumianej w kategoriach interesów, postaw i zachowań Polaków zamieszkujących ten obszar, od początku funkcjonowania Zaolzia jako przestrzeni społeczno-kulturowej (od 1920 roku, gdy doszło do podziału Śląska Cieszyńskiego między Polskę a Czechosłowację) był przedmiotem zainteresowania naukowego głównie ze strony polskich i czeskich naukowców. W literaturze naukowej dotyczącej kwestii etnicznej/narodowej na Śląsku Cieszyńskim pojawiły się również warte odnotowania dzieła autorstwa naukowców spoza naszego regionu (zob. np. Hannan, 1996a; 1996b; 1999; 2005; Witt, 1935).

Na gruncie nauk o polityce $\mathrm{z}$ wielu różnych względów tematyka zaolziańska nie była podejmowana (w odróżnieniu od badań historycznych czy etnograficznych). Do przełomu lat 80. i 90. XX wieku przyczyny tego stanu rzeczy były oczywiste. W Czechosłowacji de facto nie uprawiano nauk o polityce, w Polsce zaś istniał nieformalny zakaz zajmowania się polską mniejszością narodową w państwach ościennych, nie wspominając już o jej aktywności politycznej. Zdumiewa natomiast fakt, iż po przemianach 1989 roku zabrakło pogłębionych i kompleksowych analiz na gruncie nauk o polityce dotyczących zachowań wyborczych Polaków na Zaolziu. Uwaga ta dotyczy zwłaszcza polskiej literatury, albowiem na gruncie czeskiej politologii podjęto kilka prób analizy zachowań politycznych mniejszości narodowych i etnicznych, w tym polskiej mniejszości na Zaolziu. Opracowania te w zdecydowanej większości dotyczą form i sposobów samoorganizacji politycznej mniejszości, w zdecydowanie mniejszym stopniu odnoszą się do zachowań wyborczych w dłuższej perspektywie czasowej ze wskazaniem na określone tendencje (zob. Kopeček, 2002; 2003; Mareš, 2003; Mareš, red., 2003; Mareš et al., 2004; Mareš, Strmiska, 2006).

Zaolzie z jego problemami narodowościowymi widzieć należy w szerszej — środkowoeuropejskiej skali, zwłaszcza w odniesieniu do doświadczeń związanych z transformacją ustrojową państw tworzących Grupę Wyszehradzką. Spośród czterech państw członkowskich tylko Słowacja posiadała w swoich granicach znaczący odsetek mniejszości narodowych, w szczególności ok. 10\% mniejszości węgierskiej, która w wielu gminach w południowej części kraju stanowiła przeważającą część ludności. Władze w Bratysławie zwłaszcza w pierwszych pięciu latach istnienia suwerennej Słowacji prowadziły politykę marginalizacji ludności węgierskiej poprzez stanowienie prawa wyborczego służącego maksymalnemu rozproszeniu głosów węgierskich wyborców (np. gerrymandering). Sytuacja mniejszości węgierskiej stała się zresztą w tamtym okresie przedmiotem licznych interwencji ze strony Rady Europy, OBWE oraz Unii Europejskiej. Dopiero pod koniec lat 90. XX wieku udało się wypracować rozwiązanie kompromisowe,

1 Artykuł powstał w ramach projektu „Právní, historické a společenskovědní aspekty nových a tradičních menšin v České republice”, kód projektu DG18P02OVV064, w programie Ministerstva kultury České republiky „Národní kulturní identita II”. Artykuł w zmienionej treści uwzględniającej specyfikę zagranicznego odbiorcy ukazał się w języku angielskim w: Zenderowski, 2020. 
satysfakcjonujące przedstawicieli mniejszości węgierskiej, którzy od tamtego czasu zasiadali także w gabinetach rządowych. Pozostałe państwa: Republika Czeska, Węgry oraz Polska nie posiadały w swych granicach zbyt licznych mniejszości narodowych. W przypadku Republiki Czeskiej, prowadzącej stosunkowo liberalną politykę narodowościową, jakkolwiek największą liczebnie mniejszością byli Słowacy (ok. 300 tys., 1991), to kilkakrotnie mniejsza polska grupa narodowościowa (ok. 60 tys., 1991) stanowiła poważniejsze wyzwanie dla rządów w Pradze (o czym będzie mowa w dalszej części artykułu). Z kolei współczesna polityka etniczna rządu w Budapeszcie jest w istocie modelowym rozwiązaniem oczekiwanym przez Węgrów od krajów ościennych, w których Węgrzy stanowią znaczący odsetek ludności (głównie: Rumunia, Słowacja, Serbia). W Polsce relewantnym aktorem politycznym wśród mniejszości narodowych i etnicznych jest mniejszość niemiecka, która zamieszkuje w sposób zwarty kilkanaście gmin województwa opolskiego i dzięki temu korzysta z pewnych koncesji zawartych w ordynacji wyborczej (zwolnienie z progu wyborczego). Temat ten od czasu do czasu jest przedmiotem kontrowersji w polityce krajowej i w stosunkach bilateralnych Polski z Niemcami, albowiem o ile Niemcy w Polsce posiadają zagwarantowany ustawowo status mniejszości narodowej, o tyle wielokrotnie większa grupa Polaków zamieszkująca Niemcy z takiego statusu nie korzysta.

\section{Cel, zakres i metodologia badań}

Celem niniejszego artykułu, stanowiącego przyczynek do dalszych, bardziej pogłębionych badań ilościowych i jakościowych, jest analiza aktywności wyborczej Polaków zamieszkujących Zaolzie w aspekcie: (a) preferencji wyborczych (ideologicznych) i mobilizacji elektoratu; (b) efektywności politycznej w postaci uzyskiwanych mandatów do organów przedstawicielskich.

Uściślając zakres prowadzonych analiz, należy stwierdzić, iż zakres podmiotowy stanowią członkowie polskiej mniejszości zamieszkujący gminy o najwyższym odsetku ludności polskiej. Zakres rzeczowy stanowi aktywność wyborcza Polaków rozumiana w kategoriach „redystrybucji władzy na poszczególne jej szczeble” (Wójcicki, 2014, s. 171). Przedmiotem zainteresowania w ramach niniejszych badań są głosy wyborcze oddane w wyborach do: (a) rad gmin (wybory komunalne) w latach 1994-2018; (b) ogólnokrajowych ciał przedstawicielskich: Izby Poselskiej Parlamentu Republiki Czeskiej (Poslanecká sněmovna Parlamentu ČR) w latach 1996 - 2017, Senatu Republiki Czeskiej w latach 2000 - 2017, na urząd Prezydenta Republiki Czeskiej (Prezident republiky) — 2013, 2018. Zakres czasowy obejmuje okres 29 lat, od roku 1990 do roku 2018. W roku 1990 odbyły się pierwsze po upadku komunizmu wybory do Izby Ludowej Zgromadzenia Federalnego (Sněmovna lidu Federálního shromáždění), do Izby Narodów Zgromadzenia Federalnego (Sněmovna národů Federálniho shromáždění) oraz do Czeskiej Rady Narodowej (Česká 
národní rada), a w 1996 roku - pierwsze wybory parlamentarne w Republice Czeskiej po rozpadzie Czechosłowacji. W roku 2018 (cezura domykająca) miały zaś miejsce wybory na urząd Prezydenta Republiki Czeskiej (Prezident republiky) oraz wybory komunalne. Szczególna uwaga poświęcona zostanie jednak tym wyborom, które odbyły się już po rozpadzie Czechosłowacji, a to z dwóch powodów. Po pierwsze, postanowiono dokonać analizy zachowań wyborczych $w$ ramach jednego organizmu państwowego (zamiast dwóch). Po drugie, od 1996 roku na czeskiej scenie partyjnej funkcjonuje kilka partii politycznych zdobywających w każdych wyborach min. 5\% poparcia, a tym samym posiadających nieprzerwanie swoją reprezentację $\mathrm{w}$ parlamencie. Zakres terytorialny stanowi region określany przez Polaków mianem Zaolzia (cz. Zaolši), przez Czechów zaś mianem Śląska Cieszyńskiego leżącego w granicach Republiki Czeskiej (cz. Těšinské Slezsko $v$ České republice, Těšinsko). Termin Zaolzie nie był jednak od czasu podziału Śląska Cieszyńskiego na dwie części (polską i czechosłowacką) odnoszony do całości terytorium (Śląska Cieszyńskiego), które przypadło w udziale państwu czechosłowackiemu, na które składały się: powiat frydecki zamieszkany przez ludność czeską, powiat frysztacki (karwiński) zamieszkany przez ludność czeską i polską oraz część dawnego powiatu cieszyńskiego zamieszkanego głównie przez ludność polską. Jak zauważa Krzysztof Szelong, „Do obszaru Zaolzia zaliczyć można zatem wyłącznie te rejony Śląska Cieszyńskiego, które w 1920 r. znalazły się w granicach Czechosłowacji, ale na których ludność polska posiadała bezwzględną większość, bądź przynajmniej liczebnie dominowała w stosunku do ludności czeskiej (przy jednoczesnej znaczącej obecności ludności niemieckiej). W takim sensie zachodnia granica Zaolzia pokrywa się więc z granicą etnograficzną, która - mimo pewnej płynności - jeszcze na przełomie XIX i XX w. wyraźnie rozdzielała obszary rozsiedlenia na Śląsku Cieszyńskim ludności polskiej i czeskiej" (Zaolzie...).

Przeprowadzone badania mają charakter analizy statystycznej. Celem tych badań jest ustalenie, czy ludność polska zamieszkująca Zaolzie po pierwsze wykazuje określone skłonności (prawidłowości) do głosowania na określone partie polityczne; po drugie - w istotnym stopniu odróżnia się przez to od swoich czeskich sąsiadów. W celu zbadania aktywności wyborczej członków mniejszości polskiej odwołano się do danych zastanych w postaci wyników poszczególnych wyborów publikowanych na stronach internetowych (www.volby.cz) Czeskiego Urzędu Statystycznego (Český statistický úrad). Natrafiono jednakowoż na podstawową trudność. Polega ona na tym, że na omawianym obszarze (Zaolzie) nie istnieją okręgi lub obwody wyborcze „,czysto polskie” lub „czysto czeskie”, które można byłoby ze sobą porównywać, zakładając tożsamość etniczną jako istotną zmienną niezależną $\mathrm{w}$ przypadku dokonywanych wyborów politycznych (ideologicznych). Poza tym pamiętać należy, że równolegle istnieje wiele innych zmiennych mogących determinować takie, a nie inne decyzje wyborcze (np. status społeczno-ekonomiczny wyborców, miejsce zamieszkania - wieś bądź miasto - czy fakt pojawienia się na danej liście wyborczej wyrazistego

88 i popularnego kandydata związanego $\mathrm{z}$ regionem lub gminą). Nie chcąc jednak 
całkowicie rezygnować z metody, jaką jest analiza ilościowa (statystyczna), postanowiono zarysować specyfikę regionu w odniesieniu do zachowań wyborczych jego mieszkańców, aby uzyskane dane mogły stanowić punkt odniesienia dla późniejszych badań jakościowych przeprowadzonych z wykorzystaniem wywiadu swobodnego. W tym celu dokonano szczegółowych analiz zachowań wyborczych:

(a) mieszkańców trzech gmin, w których Polacy stanowią największy odsetek ludności, oraz trzech gmin, gdzie stanowią znikomy procent społeczności (według spisu z 2011 roku). Wszystkie te gminy, zarówno „polskie”, jak i „czeskie”2, położone są w niewielkiej odległości od siebie. Zdecydowano się zatem na wybór trzech gmin, w których ludność polska stanowi około jedną trzecią mieszkańców. „Polskie” gminy — Gródek/Hrádek (31,33\%), Milików/Milíkov (30,35\%) i Koszarzyska/Košařiska (27,93\%) — znajdują się w południowej części regionu Zaolzia i sąsiadują ze sobą. Dla porównania przeanalizowano wyniki wyborcze w ,czeskich” gminach zlokalizowanych również w południowej części Zaolzia, w których odsetek ludności polskiej jest niewielki: Herczawa/Hrčava (2,17\%), Toszonowice Dolne/Dolní Tošanovice (3,74\%) oraz Dobracice/Dobratice (0,99\%);

(b) mieszkańców (dwudziestu) gmin, w których Polacy stanowią najwyższy odsetek ludności (powyżej 15\% — „polskie” gminy), oraz mieszkańców (czternastu) gmin, w których Polacy stanowią najniższy odsetek ludności (do $5 \%$ _ „czeskie” gminy) (zob. tab. 1, 2);

(c) mieszkańców północnej (przemysłowo-górniczej, silnie zurbanizowanej) oraz południowej (rolniczo-pasterskiej, wiejskiej lub małomiasteczkowej; bez Trzyńca) części Zaolzia. Część północna pokrywa się z obszarem powiatu karwińskiego i obejmuje następujące tzw. gminy o rozszerzonych kompetencjach: Czeski Cieszyn, Karwina, Hawierzów, Orłowa i Bogumin. Część południowa obejmuje wschodnią część powiatu frydecko-misteckiego, tj. dwie gminy o rozszerzonych kompetencjach: Trzyniec i Jabłonków;

(d) mieszkańców tzw. Góralszczyzny, stanowiącej fragment południowej części Zaolzia, w której skład wchodzą następujące gminy: Boconowice/Bocanovice, Bukowiec/Bukovec, Bystrzyca/Bystřice, Dolna Łomna / Dolní Lomná, Górna Łomna / Horní Lomná, Gródek/Hrádek, Herczawa/Hrčava, Jabłonków/Jablunkov, Koszarzyska/Košařiska, Milików/Milíkov, Mosty k. Jabłonkowa / Mosty u Jablunkova, Nawsie/Návsí, Nydek/Nýdek, Pioseczna/Písečná, Piosek/Písek. Ta część Zaolzia, w odróżnieniu od części północnej, w niewielkim stopniu doświadczyła ruchów migracyjnych.

${ }^{2}$ Określenia „polskie” gminy i „,zeskie” gminy stanowią skróty myślowe na określenie odpowiednio - gmin, w których Polacy stanowią znaczącą (lecz nieprzekraczającą połowy mieszkańców) populację w danej gminie, oraz gmin, w których Polacy stanowią znikomy (poniżej 5\%) odsetek lokalnej ludności. 
Gminy na Zaolziu o najwyższym odsetku ludności polskiej (powyżej 15\%, 2011)

\begin{tabular}{|l|c|}
\hline \multicolumn{1}{|c|}{ Gmina } & \% Polaków \\
\hline Hrádek / Gródek & 31,33 \\
\hline Milíkov / Milików & 30,35 \\
\hline Košařiska / Koszarzyska & 27,93 \\
\hline Vendryně / Wędrynia & 27,12 \\
\hline Bukovec / Bukowiec & 26,06 \\
\hline Dolní Lomná / Dolna Łomna & 25,39 \\
\hline Bocanovice / Boconowice & 24,16 \\
\hline Bystřice / Bystrzyca & 24,13 \\
\hline Ropice / Ropica & 22,42 \\
\hline Horní Lomná / Górna Łomna & 21,71 \\
\hline Písečná / Pioseczna & 19,39 \\
\hline Nýdek / Nydek & 19,32 \\
\hline Smilovice / Śmiłowice & 19,08 \\
\hline Stonava / Stonawa & 18,99 \\
\hline Návsí / Nawsie & 18,58 \\
\hline Albrechtice / Olbrachcice & 17,63 \\
\hline Horní Suchá / Sucha Górna & 17,10 \\
\hline Komorní Lhotka / Ligotka Kameralna & 16,75 \\
\hline Chotěbuz / Kocobędz & 16,45 \\
\hline Řeka / Rzeka & 15,86 \\
\hline
\end{tabular}

Źródło: opracowanie własne na podstawie: Český statistický úřad. Sčítání lidu, domů a bytů. https://www.czso.cz/csu/czso/ scitani-lidu-domu-a-bytu [dostęp: 23.02.2021]; Borák, Gawrecki, red., 1992, s. 160-251.

Gminy na Zaolziu o najniższym odsetku ludności polskiej (poniżej 5\%, 2011)

\begin{tabular}{|c|c|}
\hline Gmina & \% Polaków \\
\hline Soběšovice / Szobiszowice & 0,93 \\
\hline Dobratice / Dobracice & 0,99 \\
\hline Petřvald / Pietwałd & 1,05 \\
\hline Horní Domaslavice / Domasłowice Górne & 1,77 \\
\hline Dolní Domaslavice / Domasłowice Dolne & 1,93 \\
\hline Hrčava / Herczawa & 2,17 \\
\hline Dětmarovice / Dziećmorowice & 2,18 \\
\hline Rychvald / Rychwałd & 2,44 \\
\hline Bohumín / Bogumin & 2,51 \\
\hline Havířov / Hawierzów & 3,08 \\
\hline Orlová / Orłowa & 3,60 \\
\hline Dolní Tošanovice / Toszonowice Dolne & 3,74 \\
\hline Dolní Lutyně / Lutynia Dolna & 3,91 \\
\hline Horní Tošanovice / Toszonowice Górne & 4,02 \\
\hline
\end{tabular}

Źródło: opracowanie własne na podstawie: Český statistický úřad. Sč́tání lidu, domů a bytů. https://www.czso.cz/csu/czso/ scitani-lidu-domu-a-bytu [dostęp: 23.02.2021]; Borák, Gawricki, red., 1992, s. 160—251. 
Postanowiono również sięgnąć do danych ze spisu powszechnego z 1921 roku i na tej podstawie wyodrębnić gminy (dwadzieścia), w których ludność polska stanowiła ponad 58,8\% ogółu mieszkańców oraz gminy (szesnaście), w których ludność czeska stanowiła ponad 59,3\% ogółu mieszkańców (zob. tab. 3, 4).

Tabela 3

Gminy na Zaolziu o najwyższym odsetku ludności polskiej (powyżej 58,8\%, 1921)

\begin{tabular}{|c|c|}
\hline Gmina & \% Polaków \\
\hline Košařiska / Koszarzyska & 97,5 \\
\hline Bocanovice / Boconowice & 96,8 \\
\hline Bukovec / Bukowiec & 94,9 \\
\hline Dolní Lomná / Dolna Łomna & 94,2 \\
\hline Smilovice / Śmiłowice & 92,8 \\
\hline Milíkov / Milików & 91,9 \\
\hline Nýdek / Nydek & 89,0 \\
\hline Mosty u Jablunkova / Mosty k. Jabłonkowa & 85,4 \\
\hline Řeka / Rzeka & 82,2 \\
\hline Horní Lomná / Górna Łomna & 79,7 \\
\hline Hrádek / Gródek & 78,7 \\
\hline Komorní Lhotka / Ligotka Kameralna & 76,4 \\
\hline Bystřice / Bystrzyca & 75,4 \\
\hline Petrovice u Karviné / Piotrowice k. Karwiny & 70,1 \\
\hline Horní Suchá / Sucha Górna & 67,7 \\
\hline Vendryně / Wędrynia & 65,3 \\
\hline Písek / Piosek & 65,1 \\
\hline Jablunkov / Jabłonków & 62,9 \\
\hline Albrechtice / Olbrachcice & 62,4 \\
\hline Vělopolí / Wielopole & 58,8 \\
\hline
\end{tabular}

Źródło: opracowanie własne na podstawie: Český statistický úřad. Sčíání lidu, domů a bytů. https://www.czso.cz/csu/czso/ scitani-lidu-domu-a-bytu [dostęp: 23.02.2021]; Borák, Gawrecki, red., 1992, s. 160—251.

Tabela 4

Gminy na Zaolziu o najwyższym odsetku ludności czeskiej (powyżej 59,3\%, 1921)

\begin{tabular}{|l|c|}
\hline \multicolumn{1}{|c|}{ Gmina } & \% Czechów \\
\hline Dolní Domaslavice / Domasłowice Dolne & 99,8 \\
\hline Horní Domaslavice / Domasłowice Górne & 99,7 \\
\hline Soběšovice / Szobiszowice & 97,7 \\
\hline Hrčava / Herczawa & 97,5 \\
\hline Dolní Tošanovice / Toszonowice Dolne & 96,0 \\
\hline Dobratice / Dobracice & 95,1 \\
\hline Rychvald / Rychwałd & 92,2 \\
\hline Petřvald / Pietwałd & 91,0 \\
\hline Dětmarovice / Dziećmorowice & 88,0 \\
\hline Orlová / Orłowa & 81,6 \\
\hline
\end{tabular}


cd. tab. 4

\begin{tabular}{|l|c|}
\hline Doubrava / Dąbrowa & 80,7 \\
\hline Dolní Lutyně / Lutynia Dolna & 79,4 \\
\hline \multirow{2}{*}{ Těrlicko / Cierlicko } & $65,5(\mathrm{~d})$ \\
\hline Horní Tošanovice / Toszonowice Górne & $43,1(\mathrm{~h})$ \\
\hline Stř́tež / Trzycież & 65,5 \\
\hline Třanovice / Trzanowice & 59,4 \\
\hline
\end{tabular}

d-Dolní Těrlicko

$\mathrm{h}$ - Horní Těrlicko

Źródło: opracowanie własne na podstawie: Český statistický úřad. Sčitání lidu, domů a bytů. https://www.czso.cz/csu/czso/ scitani-lidu-domu-a-bytu [dostęp: 23.02.2021]; Borák, Gawrecki, red., 1992, s. 160—251.

\section{Mniejszości narodowe jako aktorzy polityczni}

Mniejszości etniczne lub narodowe na ogół przejawiają wolę posiadania swojej reprezentacji politycznej na poszczególnych szczeblach władzy publicznej począwszy od samorządu lokalnego, przez szczebel regionalny (np. samorządowe województwa), po szczebel centralny (parlament, urzędy centralne). Im liczniejsza mniejszość, tym zwykle większe ambicje polityczne. Mniej liczebne mniejszości zadowalają się posiadaniem odpowiedniej reprezentacji na szczeblu gminnym, powiatowym czy regionalnym; bardziej liczebne, a do tego skoncentrowane na określonym obszarze, mają ambicję kształtowania polityki w wymiarze co najmniej regionalnym. Zdarza się też, że ich partie polityczne wchodzą w skład koalicji rządowych lub wspierają rząd bez umowy koalicyjnej w zamian za pewne koncesje dla swojej wspólnoty narodowej (vide: partie węgierskiej mniejszości narodowej wchodzące w skład koalicji rządowych na Słowacji i w Rumunii, partia turecka współtworząca gabinet rządowy w Bułgarii, partia polska na Litwie). Swoistym kuriozum jest przypadek serbskiej partii (Lista Serbska), która do 2018 roku wchodziła w skład koalicji rządowej Kosowa - państwa nieuznawanego oficjalnie przez rząd w Belgradzie.

Wydaje się, że coraz powszechniejsze staje się przekonanie, iż dzięki partycypacji przedstawicieli mniejszości $w$ danym systemie politycznym i partyjnym latwiej jest uniknąć dyskryminujących praktyk ze strony państwa (i narodu większościowego) w zakresie praw kulturowych, społecznych czy ekonomicznych. Rafał Woźnica zauważa, że „,brak uczestnictwa w instytucjach państwowych, a co za tym idzie marginalizacja mniejszości, może prowadzić do alienacji mniejszości w stosunku do państwa zamieszkania. W rezultacie często wśród mniejszości brak jest poczucia przynależności do państwa, które postrzegane jest jako wyłączna domena większości. Reakcją może być uciekanie się do środków pozainstytucjonalnych obejmujących bardzo szeroki wachlarz działań, od tworzenia instytucji 
równoległych (alternatywnych) czy organizacji pozaparlamentarnych aż do zbrojnych ruchów secesyjnych” (Woźnica, 2016, s. 187-188). Najczęściej owocuje to procesem gettoizacji danej grupy mniejszościowej.

Posiadanie reprezentacji politycznej przez mniejszość narodową lub etniczną może przyjmować dwojaką formę. Po pierwsze, mniejszość może zabiegać o posiadanie własnego ugrupowania politycznego - partii etnicznej lub partii (etno)regionalnej funkcjonującej w środowisku wyłącznie lokalnym bądź też mającej ambicję podejmowania działalności na szczeblu centralnym polityki krajowej. Ugrupowanie takie może tworzyć jedna mniejszość, ale możliwe jest także zawieranie sojuszy z innymi mniejszościami etnicznymi/narodowymi zamieszkującymi dane państwo w celu stworzenia możliwie jak najsilniejszej reprezentacji interesów mniejszościowych. Po drugie, dana mniejszość etniczna/narodowa może uznać za wystarczające i pożądane włączanie się w struktury polityczne i oddziaływanie na procesy decyzyjne za pośrednictwem istniejących już ogólnokrajowych partii politycznych, nierzadko negocjując z nimi rodzaj współpracy politycznej, w tym umieszczanie kandydatów mniejszości na listach wyborczych danej partii na takich pozycjach, że istnieje duże prawdopodobieństwo uzyskania mandatu. Pomiędzy tymi obydwoma zasadniczo różnymi modelami partycypacji politycznej mniejszości etnicznych/narodowych istnieje swego rodzaju wariant pośredni, polegający na wytworzeniu instytucji niebędącej partią polityczną (etniczną), która ma służyć koordynowaniu wysiłków zmierzających do zdobycia odpowiedniej reprezentacji politycznej (posłów, senatorów, radnych itp.). Mowa tutaj o różnego rodzaju stowarzyszeniach i ruchach obywatelskich, które w sposób ciągły lub ad hoc starają się tworzyć platformę współpracy różnych opcji politycznych funkcjonujących w ramach danej grupy mniejszościowej, w celu wyłonienia takich kandydatów, którzy ostatecznie odniosą sukces wyborczy.

Wydawać by się mogło, że posiadanie relewantnej partii etnicznej, funkcjonującej w systemie politycznym danego państwa, stanowi optymalne rozwiązanie, patrząc z perspektywy interesów danej mniejszości. Zanim jednak odniesiemy się do tej kwestii, należy w kilku zdaniach doprecyzować pojęcie partii etnicznej. Martyna Wasiuta zauważa, że partie etniczne nie są typowymi partiami politycznymi; wskazuje jednocześnie na dwa podejścia do rozumienia ich istoty. Podejście strukturalne ,pozwala na określenie ich takim mianem, ponieważ są organizacjami zrzeszającymi członków, posiadającymi swoją strukturę (kierownictwo etc.), dążącymi do objęcia stanowisk w państwie" (Wasiuta, 207, s. 3). Tymczasem podejście funkcjonalne umożliwia wykluczenie partii etnicznej ,z grona klasycznych partii politycznych, ponieważ partie etniczne [...] nie agregują interesów, ale podkreślają ich partykularyzm oraz nie integrują społeczeństwa i nie kreują społecznego konsensu” (Wasiuta, 2017, s. 3). Wasiuta stwierdza jednocześnie, że „To, co osłabia ich kondycję jako partii politycznych według jednych badaczy, przez innych jest rozpatrywane już na korzyść partii etnicznych sensu stricto. Ich udział w systemie partyjnym pozwala na uwzględnianie interesów podzielonego społeczeństwa, nie wyklucza jego segmentów, przez co pozwala na instytucjonalne skanalizowanie nastrojów etnicznych, oddalając groźbę niekontrolowanego konfliktu oraz stanowi 
przejaw demokratycznego konsocjonalizmu" (Wasiuta, 2017, s. 3) 3. Według literatury politologicznej do kategorii partii etnicznej zaliczyć można: partie etnopolityczne (ang. ethnopolitical parties), partie mniejszości etnicznych lub narodowych (ang. minority parties), partie regionalne (ang. regionalist parties) i partie etnoregionalne (ang. ethnoregionalist parties), a także partie wieloetniczne (ang. multiethnic parties). Ich wspólnym mianownikiem jest „oparta na kryteriach etnicznych (regionalnych) struktura członkowska i kierownictwo, elektorat i typ apelu, z których z kolei wynikają szczególne funkcje, jakie wypełniają one względem grupy etnicznej i jej otoczenia. Partie te bazują na rozłamach socjopolitycznych centrum-peryferie lub na podziale etnoregionalnym" (Wasiuta, 2017, s. $3-4)^{4}$.

Wasiuta, dokonując analizy i syntezy różnych definicji partii etnicznej, pisze, że według Donalda Horovitza partia etniczna jest „organizacją polityczną, znajdującą się pomiędzy partią polityczną a grupą interesu" (Wasiuta, 2017, s. 4). Paul R. Brass opisuje ją jako ,pewną organizację polityczną dominującą w reprezentowaniu żądań określonej grupy etnicznej, w opozycji do jej rywali” (Wasiuta, 2017, s. 4). Z kolei według Kanchan Chandry i Davida Metza ,partia etniczna to partia otwarcie przedstawiająca się wyborcom jako obrońca interesów jednej grupy etnicznej lub agregatu grup przed wykluczeniem ich przez inną grupę lub grupy, i osadzająca tę reprezentację w centrum w swojej strategii mobilizacyjnej" (Wasiuta, 2017, s. 4). Donna L. Van Cott zaś proponuje, by ,partią etniczną nazywać organizację uprawnioną do rywalizacji wyborczej, której większość przywódców i członków identyfikuje się z grupą etniczną niedominującą i której główne hasła programu wyborczego zawierają żądania o charakterze etnicznym i kulturowym" (Wasiuta, 2017, s. 4). Wasiuta zauważa, że „do cech, na podstawie których klasyfikuje się partie etniczne, należą: wielkość poparcia, które partia otrzymuje w wyborach od danej grupy etnicznej, od której jest uzależniona, oraz to, czy partia przedstawia siebie jako reprezentanta tejże grupy. Partia etniczna jako taka nie byłaby etniczną, gdyby nie otrzymywała większości poparcia od konkretnej grupy etnicznej i nie określała w tych kategoriach samej siebie (zwłaszcza w nazwie partii), wykluczając w ten sposób inne segmenty elektoratu" (Wasiuta, 2017, s. 4).

Jak już stwierdzono, partia etniczna niekoniecznie musi reprezentować interes jednej mniejszości etnicznej/narodowej. Możliwe jest bowiem stworzenie swego rodzaju sojuszu partyjnego dwóch lub więcej mniejszości etnicznych. Doskonałym przykładem takiego ,sojuszu” mniejszości jest Ruch Polityczny CoexistentiaWspólnota-Együttélés - Spivžitja-Soužití_Zusammenleben, powstały w 1989 roku jako Ruch Polityczny Mniejszości Narodowych w Czechosłowacji „Coexistentia”. Jest to ugrupowanie polityczne działające początkowo wśród mniejszości narodowych Czechosłowacji, następnie zaś w Republice Czeskiej, mające na celu zabezpieczenie praw mniejszości narodowych i etnicznych. W drugiej dekadzie

${ }^{3}$ Zob. także: Horovitz, 1985, s. 296-297; Ishiyama, 2001; Herbut, 2002, s. 28-31; Touquet, 2011.

${ }^{4}$ Zob. także: Lipset, Rokkan, 1967, s. 16; De Winter, Türsan, 2003, s. 1.

$945{ }^{5}$ Zob. także: Horovitz, 1985, s. 291; Van Cott, 2005, s. 3; Ishiyama, Breuning, 2011. 
XXI wieku w Serbii w wyborach parlamentarnych wystartowało ugrupowanie pod nazwą Lista Wspólnot Narodowych (Lista nacionalnih zajednica) zrzeszające kilka mniejszości narodowych zamieszkujących Serbię (Węgrów, Chorwatów, Boszniaków).

Z drugiej strony mniejszość etniczna/narodowa, pod warunkiem, że jest dostatecznie duża, może utworzyć dwie lub więcej partii politycznych będących de facto partiami etnicznymi, a przez to niejako kształtować paralelną scenę partyjną w danym kraju (odzwierciedlającą podziały ideologiczne wewnątrz danej wspólnoty mniejszościowej). Rzadkim zjawiskiem są partie polityczne międzyetniczne, które otwarcie zmierzają do wypracowania jakiegoś konsensusu pomiędzy mniejszością etniczną/narodową a narodem większościowym poprzez promowanie pojednania, współpracę międzyetniczną oraz przełamywanie wzajemnych uprzedzeń i stereotypów. W odróżnieniu od innych partii politycznych promujących przełamywanie barier międzyetnicznych ten typ partii cechuje silne akcentowanie tożsamości etnicznej i postulatu zachowania odrębnej tożsamości narodowej.

\section{Aksamitna rewolucja i początki politycznej samoorganizacji mniejszości polskiej na Zaolziu}

Część Polaków aktywnie zaangażowała się w działalność Forum Obywatelskiego, tworząc w pewnym momencie w jego ramach ,sekcję polską", a w późniejszym czasie angażowała się także w tworzenie struktur nowych partii politycznych, zwłaszcza ODS, KDU-ČSL czy ČSSD. Z drugiej strony część działaczy polskich, także i tych pierwotnie działających w ramach Forum Obywatelskiego, na początku lat 90. XX wieku aktywnie zaangażowała się w tworzenie ugrupowania mającego stanowić reprezentację wszystkich mniejszości narodowych i etnicznych w ówczesnym państwie czechosłowackim: Wspólnota-Soužití-Egüttélés (COEX). Ugrupowanie to wraz z rozpadem Czechosłowacji, a tym samym pozostaniem zdecydowanie większej części mniejszości narodowych i etnicznych po słowackiej stronie granicy, stało się w nowych warunkach ustrojowych (Republika Czeska) ugrupowaniem jednoznacznie kojarzonym z polską mniejszością narodową. Przy czym z uwagi na utratę „węgierskiego komponentu” partia ta przestała odgrywać jakąkolwiek rolę w wymiarze ogólnokrajowym (wybory parlamentarne), a jej przedstawiciele skoncentrowali swoją aktywność na lokalnym wymiarze polityki (wybory samorządowe). Faktem jest, że aktywność polityczna reprezentantów polskiej mniejszości od początku lat 90 . XX wieku miała niejako dwuwektorowy charakter (Kopeček, 2002; 2003).

$\mathrm{Z}$ jednej strony występowali bowiem ci, którzy optowali - mówiąc w pewnym uproszczeniu — za ,zasadą obywatelską" i realizacją interesów polskiej mniejszości na zasadzie współpartycypacji z Czechami w podejmowaniu różnych 
projektów politycznych. W tym przypadku zakładano, iż działalność polityczna powinna mieć w pierwszym rzędzie obywatelski, ponadetniczny wymiar, realizację praw mniejszości widziano zaś na drodze konsensusu i kooperacji z narodem większościowym (Czechami). W gronie działaczy politycznych omawianego nurtu znaleźli się m.in.: Marian Siedlaczek, Tadeusz Wantuła, Jan Rusnok, Janusz Klimsza (Kopeček, 2003).

Z drugiej strony aktywność przejawiali ci przedstawiciele polskiej mniejszości, którzy optowali za „zasadą narodową” oraz wyraźnym określeniem i realizacją interesów polskiej grupy w postaci paralelnych instytucji społeczno-kulturalnych, a przede wszystkim - partii politycznych (wzorcem dla tego typu polityki były strategie polityczne Węgrów słowackich). W odróżnieniu od swoich rodaków z opcji liberalno-obywatelskiej stawiających na kooperację z władzami państwowymi i narodem większościowym, zwolennicy tej drogi realizacji interesów polskich na Zaolziu postawili na ścisłą kooperację z reprezentacjami innych mniejszości narodowych i etnicznych. Kluczową rolę odgrywało tutaj porozumienie z półmilionową mniejszością węgierską jako najliczniejszą w Czechosłowacji i będącą w podobnym położeniu co polska (zwarte występowanie przy granicy z państwem macierzystym, długowieczna historia osadnictwa, wysoki poziom samoświadomości i odrębności narodowej, istnienie podziałów wyznaniowych wewnątrz grupy „wyciszanych” przez interesy narodowe). Nie bez znaczenia było zapewne i to, że na początku lat 90 . XX wieku bardzo silny rezonans polityczny miały postulaty polityków słowackich domagających się autonomii lub suwerenności Słowacji. W gronie działaczy politycznych omawianego nurtu znaleźli się m.in.: Stanisław Gawlik, Edwin Macura, Władysław Niedoba (Kopeček, 2003) (notabene Gawlik i Niedoba startowali do parlamentu czechosłowackiego... ze słowackich okręgów wyborczych).

\section{Wybory lokalne (komunalne) na Zaolziu (1994-2018)}

Od początku lat 90. XX wieku elity zaolziańskie, zyskując stopniowo świadomość niewielkiego wpływu na politykę ogólnokrajową czy nawet regionalną - wojewódzką (niewielkich szans dla odpowiednich koncesji na rzecz polskiej mniejszości), coraz więcej energii poświęcały polityce lokalnej samorządowej. Samorządy gminne stały się zatem sprawdzianem politycznej samoorganizacji polskiej mniejszości, której przedstawiciele bynajmniej nie mieli jednolitej strategii forsowania polskich interesów. Otóż podobnie jak w odniesieniu do polityki ogólnokrajowej, począwszy od lat 90. XX wieku, także i w tym przypadku wyraźna jest swoista dwutorowość w stosunku do strategii wyborczej. 
$\mathrm{Z}$ jednej bowiem strony panuje przekonanie, że aby być skutecznym politykiem lokalnym, należy uzyskać możliwie szerokie poparcie wyborcze, co w praktyce oznacza budowanie bazy wyborczej (elektoratu) ponad podziałami etnicznymi. Zwolennicy takiej strategii odwołują się w pierwszym rzędzie do interesu danego regionu jako całości, nie zaś do interesów polskiej lub czeskiej grupy narodowościowej. W efekcie zdarza się, że polski kandydat uzyskuje więcej czeskich aniżeli polskich głosów wyborczych, co może w przyszłości przekładać się na sukces wyborczy w wyborach ogólnokrajowych.

Z drugiej strony część zaangażowanych społecznie i politycznie Polaków stoi na stanowisku, że w pierwszym rzędzie należy bronić interesu polskiej grupy narodowościowej, dążąc do mobilizacji elektoratu glównie wśród Polaków zaolziańskich, względnie także wśród innych mniejszości narodowych i etnicznych (poprzez odwoływanie się do wspólnych, mniejszościowych interesów). Owszem, dostrzega się konieczność współdziałania na rzecz danego regionu i realizacji jego ponadetnicznych interesów, jednakowoż powinno się to odbywać z pozycji odrębnej, polskiej organizacji, posiadającej swoją podmiotowość polityczną.

Wydaje się, że z czasem zaczyna przeważać pierwsza z wyżej wymienionych strategii, zwłaszcza, iż liczebność osób deklarujących się jako Polacy systematycznie spada. Nie oznacza to jednak absolutnie „rozluźnienia” dyscypliny wśród tych lokalnych działaczy, którzy stawiają na „mobilizację etniczną” Polaków mieszkających na Zaolziu.

Analiza statystyczna $\mathrm{w}$ odniesieniu do przedstawicieli pierwszego nurtu nastręcza pewnych trudności, albowiem Polacy lub osoby polskiego pochodzenia w wyborach lokalnych na ogół stawiają na pierwszym planie kwestie interesów danego regionu i nie eksponują swojej tożsamości narodowej. Zdarza się wcale nierzadko, że są oni bardzo skuteczni w pozyskiwaniu głosów wyborczych zarówno Polaków, jak i Czechów, a także osób deklarujących inną tożsamość narodową (Ślązacy, Słowacy, Węgrzy, Romowie itd.).

W odniesieniu do drugiego ze wspomnianych nurtów, z oczywistych względów zdecydowanie łatwiej jest przeprowadzić analizę statystyczną. W tym kontekście warto więcej uwagi poświęcić ugrupowaniu o nazwie Coexistentia-Wspólnota (Coexistentia-Soužití - COEX), które wraz z rozpadem Czechosłowacji z partii o zasięgu ogólnokrajowym, reprezentującej kilka mniejszości narodowych i etnicznych, stało się partią, a raczej ruchem społecznym o zasięgu lokalnym, reprezentującym de facto wyłącznie mniejszość polską ${ }^{6}$. Jak zauważa Wasiuta, „transformację tę można opisać w skrócie jako przemianę wieloetnicznej partii typu niepodległościowego $\mathrm{w}$ partię monoetniczną umiarkowanego protekcjonizmu. Główną przyczyną tego przeobrażenia się była zmiana polityczno-ustrojowa z 1993 r. Formalnie COEX nadal pozostaje ruchem politycznym, spełniając jednak funkcje partii politycznej" (Wasiuta, 2017, s. 13). Po rozpadzie Czechosłowacji liderzy tego ugrupowania podjęli kilka bezskutecznych prób uzyskania mandatu

${ }^{6}$ Szerzej na temat politycznej samoorganizacji i zachowań politycznych Polaków zaolziańskich: Kopeček, 2002; 2003. 
poselskiego poprzez wejście $\mathrm{w}$ koalicję $\mathrm{z}$ innymi podmiotami o bardzo niewielkim poparciu społecznym (1996 r. — z ruchem Niezawisłych — NEZÁVISLÍ; 2002 r. - z Partią Wsi - Strana venkova - spojené občanské síly). Podobnie zresztą było w odniesieniu do wyborów wojewódzkich. W ówczesnym województwie ostrawskim w 2000 roku, w pierwszych wyborach do sejmiku wojewódzkiego COEX uzyskał 2,31\% poparcia w skali województwa, w powiecie karwińskim $-5,85 \%$, frydecko-misteckim zaś $-5,64 \%$. W późniejszych wyborach COEX już nie startowała. W 2006 roku ostatecznie postanowiono zrezygnować z aktywności politycznej o zasięgu ogólnopaństwowym oraz wojewódzkim i skoncentrować się na lokalnej polityce (Wasiuta, 2017, s. 14-15). Mając na uwadze okres 1994-2018 i poparcie dla kandydatów COEX w wyborach gminnych (startujących pod szyldem COEX, nie w koalicji z innymi podmiotami), należy odnotować, że zauważalny stopniowy spadek liczby oddanych głosów z prawie 85 tys. w 1994 roku do nieco ponad 33 tys. głosów w 2018 roku nie przekłada się na proporcjonalny spadek liczby uzyskanych mandatów: 39 w 1994 i 32 w 2018 roku. Świadczyć to może o doskonaleniu strategii wyborczej, w efekcie której radykalnie obniżono liczbę tzw. zmarnowanych głosów, które nie skutkują uzyskaniem mandatu przez reprezentanta omawianego ugrupowania (zob. rys. 1, 2).

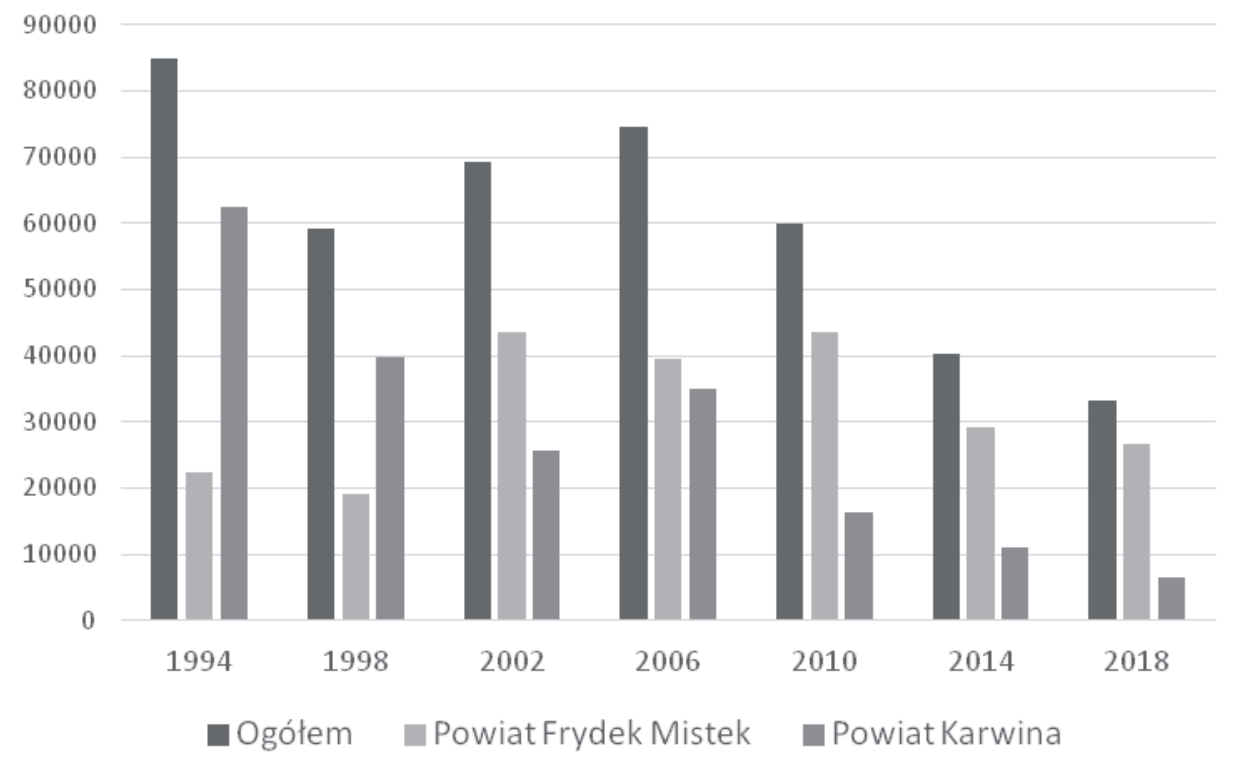

Rys. 1. Liczba głosów oddanych na kandydatów COEX w wyborach samorządowych (lokalnych) w latach 1994-2018

Źródło: opracowanie własne na podstawie: Český statistický úřad: Volby.cz. https://volby.cz [dostęp: 23.02.2021]. 


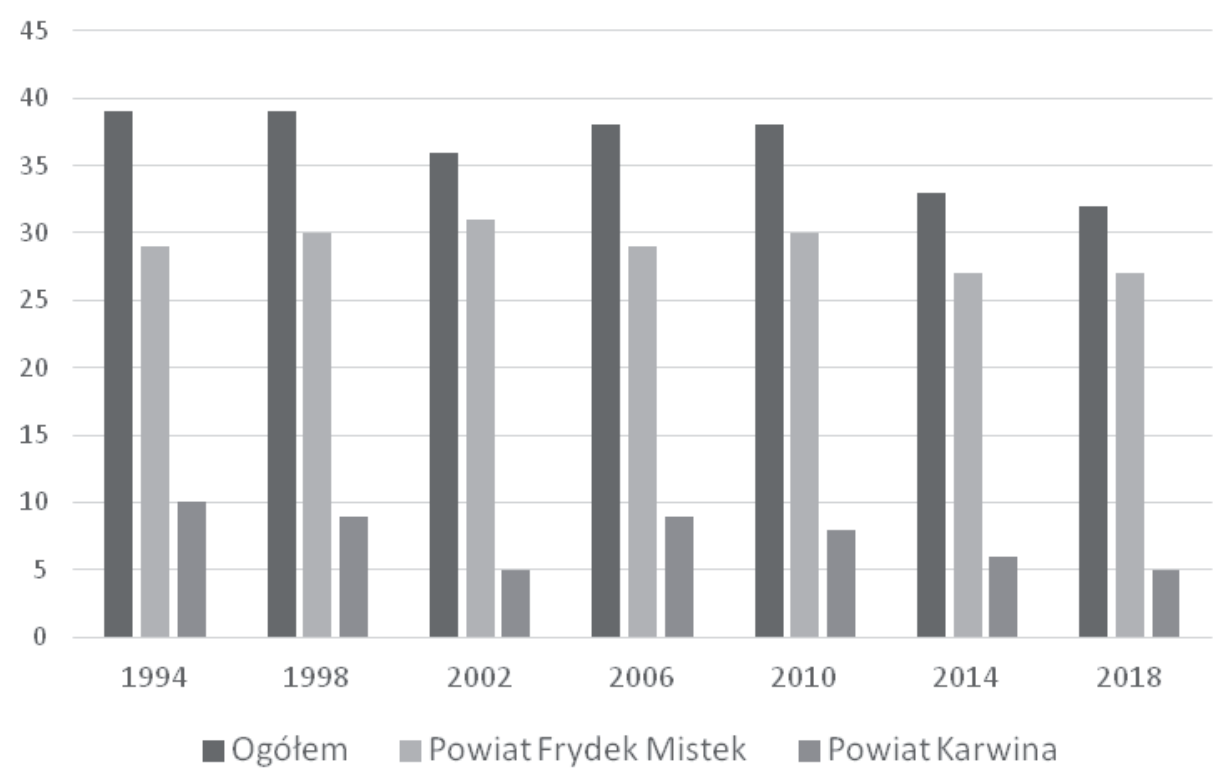

Rys. 2. Liczba mandatów uzyskanych przez kandydatów COEX w wyborach samorządowych (lokalnych) w latach 1994-2018

Źródło: opracowanie własne na podstawie: Český statistický úřad: Volby.cz. https://volby.cz [dostęp: 23.02.2021].

Na stronie internetowej COEX (Polacy w radach miast i gmin...) znajdziemy listę wszystkich polskich radnych w gminach czeskiej części Śląska Cieszyńskiego (czyli także nienależących do COEX), których w kadencji 2018-2022 w sumie jest 105 (na 692 wszystkich mandatów radnych). Naturalnie mamy $\mathrm{w}$ omawianym przypadku do czynienia $\mathrm{z}$ pewną uznaniowością dotyczącą politycznego znaczenia tożsamości narodowej, zwłaszcza w odniesieniu do osób wybranych na radnych spoza listy COEX. Ich polskość została co prawda "potwierdzona" przez COEX na oficjalnej stronie internetowej, co już samo w sobie stanowi interesujący przyczynek do badań nad „odgórnym” rozstrzyganiem tożsamości narodowej/etnicznej. Należy jednak z dużym prawdopodobieństwem założyć, że sami zainteresowani raczej utożsamiają się z polską grupą narodową, albowiem nie odnotowano jakichś sprzeciwów wobec zawartości omawianej listy ze strony osób, których nazwiska pojawiły się na tejże liście. Można natomiast przypuszczać, że lista polskich radnych zamieszczona na oficjalnej stronie COEX może być niepełna, gdyż nie wszyscy faktycznie polscy kandydaci, w uznaniu redaktorów tej listy, zasłużyli sobie na miano ,polskich radnych". Dlatego też przedstawiane dane należy traktować z pewną ostrożnością (zob. tab. 5). 
Tabela 5

Polscy radni w poszczególnych gminach Zaolzia (wybory samorządowe w 2018 r.)

\begin{tabular}{|c|c|c|c|c|c|c|c|}
\hline Gmina & $\begin{array}{c}\text { Ogólem } \\
\text { mandatów } \\
\text { w gminie }\end{array}$ & $\operatorname{COEX}^{\mathrm{a})}$ & $\begin{array}{c}\text { PL } \\
\text { spoza } \\
\text { COEX }\end{array}$ & $\begin{array}{l}\text { Lącznie } \\
\text { PL }\end{array}$ & $\begin{array}{c}\% \\
\text { mandatów } \\
\text { dla PL }\end{array}$ & 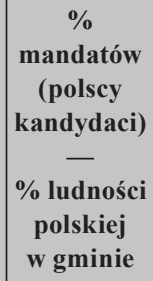 & $\begin{array}{c}\% \\
\text { Polaków } \\
\text { w gminie }\end{array}$ \\
\hline Albrechtice / Olbrachcice & 15 & 1 & 5 & 6 & 40,00 & $\uparrow \uparrow \uparrow \uparrow$ & 17,63 \\
\hline Bocanovice / Boconowice & 7 & 0 & 1 & 1 & 14,29 & $\downarrow \downarrow$ & 24,16 \\
\hline Bohumín / Bogumin & 23 & 0 & 0 & 0 & 0,00 & $\bullet$ & 2,51 \\
\hline Bukovec / Bukowiec & 11 & 2 & 1 & 3 & 27,27 & $\bullet$ & 26,06 \\
\hline Bystřice / Bystrzyca & 15 & 0 & 5 & 5 & 33,33 & $\uparrow$ & 24,13 \\
\hline $\begin{array}{l}\text { Český Těšín / } \\
\text { Czeski Cieszyn }\end{array}$ & 27 & 0 & 7 & 7 & 25,93 & $\uparrow \uparrow$ & 12,76 \\
\hline Chotěbuz / Kocobędz & 15 & 2 & 1 & 3 & 20,00 & $\bullet$ & 16,45 \\
\hline $\begin{array}{l}\text { Dětmarovice / } \\
\text { Dziećmorowice }\end{array}$ & 15 & 0 & 0 & 0 & 0,00 & $\bullet$ & 2,18 \\
\hline Dobratice / Dobracice & 9 & 0 & 0 & 0 & 0,00 & $\bullet$ & 0,99 \\
\hline $\begin{array}{l}\text { Dolní Domaslavice / } \\
\text { Domasłowice Dolne }\end{array}$ & 15 & 0 & 0 & 0 & 0,00 & $\bullet$ & 1,93 \\
\hline $\begin{array}{l}\text { Dolní Lomná / Dolna } \\
\text { Lomna }\end{array}$ & 7 & 1 & 2 & 3 & 42,86 & $\uparrow \uparrow \uparrow$ & 25,39 \\
\hline $\begin{array}{l}\text { Dolní Lutyně / } \\
\text { Lutynia Dolna }\end{array}$ & 15 & 1 & 0 & 1 & 6,67 & $\uparrow$ & 3,91 \\
\hline $\begin{array}{l}\text { Dolní Tošanovice / } \\
\text { Toszonowice Dolne }\end{array}$ & 9 & 0 & 0 & 0 & 0,00 & $\bullet$ & 3,74 \\
\hline Doubrava / Dąbrowa & 15 & 0 & 1 & 1 & 6,67 & $\bullet$ & 5,67 \\
\hline Havířov / Hawierzów & 43 & 0 & 4 & 4 & 9,30 & $\uparrow$ & 3,08 \\
\hline $\begin{array}{l}\text { Horní Domaslavice / } \\
\text { Domaslowice Górne }\end{array}$ & 13 & 0 & 0 & 0 & 0,00 & $\bullet$ & 1,77 \\
\hline $\begin{array}{l}\text { Horní Lomná / } \\
\text { Górna Lomna }\end{array}$ & 7 & 0 & 1 & 1 & 14,29 & $\downarrow$ & 21,71 \\
\hline $\begin{array}{l}\text { Horní Suchá / } \\
\text { Sucha Górna }\end{array}$ & 15 & 0 & 5 & 5 & 33,33 & $\uparrow \uparrow \uparrow$ & 17,10 \\
\hline $\begin{array}{l}\text { Horní Tošanovice / } \\
\text { Toszonowice Górne }\end{array}$ & 9 & 0 & 1 & 1 & 11,11 & $\uparrow$ & 4,02 \\
\hline Hrádek / Gródek & 15 & 4 & 3 & 7 & 46,67 & $\uparrow \uparrow \uparrow$ & 31,33 \\
\hline Hrčava / Herczawa & 7 & 0 & 0 & 0 & 0,00 & $\bullet$ & 2,17 \\
\hline Jablunkov / Jabłonków & 21 & 1 & 2 & 3 & 14,29 & $\bullet$ & 14,60 \\
\hline Karviná / Karwina & 41 & 0 & 4 & 4 & 9,76 & $\bullet$ & 9,73 \\
\hline
\end{tabular}


cd. tab. 5

\begin{tabular}{|l|c|c|c|c|c|c|c|}
\hline $\begin{array}{l}\text { Komorní Lhotka / } \\
\text { Ligotka Kameralna }\end{array}$ & 11 & 0 & 1 & 1 & 9,09 & $\downarrow$ & 16,75 \\
\hline Košařiska / Koszarzyska & 9 & 2 & 1 & 3 & 33,33 & $\uparrow$ & 27,93 \\
\hline Milíkov / Milików & 13 & 6 & 1 & 7 & 53,85 & $\uparrow \uparrow \uparrow \uparrow$ & 30,35 \\
\hline $\begin{array}{l}\text { Mosty u Jablunkova / } \\
\text { Mosty k. Jabłonkowa }\end{array}$ & 15 & 3 & 1 & 4 & 26,67 & $\uparrow \uparrow$ & 13,42 \\
\hline Návsí / Nawsie & 15 & 2 & 2 & 4 & 26,67 & $\uparrow$ & 18,58 \\
\hline Nýdek / Nydek & 15 & 2 & 0 & 2 & 13,33 & $\downarrow$ & 19,32 \\
\hline Orlová / Orlowa & 31 & 0 & 1 & 1 & 3,23 & $\bullet$ & 3,60 \\
\hline $\begin{array}{l}\text { Petrovice u Karviné / } \\
\text { Piotrowice k. Karwiny }\end{array}$ & 21 & 0 & 1 & 1 & 4,76 & $\downarrow$ & 13,05 \\
\hline Petřvald / Pietwałd & 15 & 0 & 0 & 0 & 0,00 & $\bullet$ & 1,05 \\
\hline Písečná / Pioseczna & 7 & 0 & 3 & 3 & 42,86 & $\uparrow \uparrow \uparrow \uparrow$ & 19,39 \\
\hline Písek / Piosek & 9 & 1 & 0 & 1 & 11,11 & $\bullet$ & 14,88 \\
\hline Řeka / Rzeka & 9 & 0 & 0 & 0 & 0,00 & $\downarrow \downarrow \downarrow$ & 15,86 \\
\hline Ropice / Ropica & 15 & 3 & 0 & 3 & 20,00 & $\bullet$ & 22,42 \\
\hline Rychvald / Rychwald & 15 & 0 & 0 & 0 & 0,00 & $\bullet$ & 2,44 \\
\hline Smilovice / Śmilowice & 7 & 0 & 1 & 1 & 14,29 & $\downarrow$ & 19,08 \\
\hline Soběšovice / Szobiszowice & 15 & 0 & 0 & 0 & 0,00 & $\bullet$ & 0,93 \\
\hline Stonava / Stonawa & 7 & 0 & 3 & 3 & 42,86 & $\uparrow \uparrow \uparrow \uparrow$ & 18,99 \\
\hline Stř́tež / Trzycież & 9 & 0 & 0 & 0 & 0,00 & & 13,66 \\
\hline Těrlicko / Cierlicko & 15 & 1 & 1 & 2 & 13,33 & $\uparrow$ & 10,89 \\
\hline Třanovice / Trzanowice & 15 & 0 & 2 & 2 & 13,33 & $\bullet$ & 15,74 \\
\hline Třinec / Trzyniec & 33 & 0 & 4 & 4 & 12,12 & $\bullet$ & 13,17 \\
\hline Vělopolí / Wielopole & 5 & 0 & 0 & 0 & 0,00 & $\downarrow \downarrow$ & 13,94 \\
\hline Vendryně / Wędrynia & 17 & 7 & 1 & 8 & 47,06 & $\uparrow \uparrow \uparrow \uparrow$ & 27,12 \\
\hline Ogólem (Zaolzie) & $\mathbf{6 9 2}$ & $\mathbf{3 9}$ & $\mathbf{6 6}$ & $\mathbf{1 0 5}$ & $\mathbf{1 5 , 1 7}$ & $\uparrow$ & $\mathbf{7 , 8 0}$ \\
\hline COEXISTENTA sack & & & & & & & \\
\hline
\end{tabular}

a) COEXISTENTIA samodzielnie lub w koalicji

\section{Legenda:}

- różnica do $5 \%$

$\uparrow \quad \%$ odsetek Polaków w gminie $<\%$ mandatów uzyskanych przez Polaków (różnica $5-10 \%$ )

$\uparrow \uparrow \quad \%$ odsetek Polaków w gminie $<\%$ mandatów uzyskanych przez Polaków (różnica $10-15 \%$ )

$\uparrow \uparrow \uparrow \quad \%$ odsetek Polaków w gminie $<\%$ mandatów uzyskanych przez Polaków (różnica 15-20\%)

$\uparrow \uparrow \uparrow \uparrow \%$ odsetek Polaków w gminie $<\%$ mandatów uzyskanych przez Polaków (różnica powyżej 20\%)

$\downarrow \quad \%$ odsetek Polaków w gminie $<\%$ mandatów uzyskanych przez Polaków (różnica 5-10\%)

$\downarrow \downarrow \quad \%$ odsetek Polaków w gminie $<\%$ mandatów uzyskanych przez Polaków (różnica 10—15\%)

$\downarrow \downarrow \downarrow \quad \%$ odsetek Polaków w gminie $<\%$ mandatów uzyskanych przez Polaków (różnica $15-20 \%$ )

$\downarrow \downarrow \downarrow \downarrow \%$ odsetek Polaków w gminie < \% mandatów uzyskanych przez Polaków (różnica powyżej 20\%)

Źródło: opracowanie własne na podstawie: www.volby.cz [dostęp: 23.02.2021]; http://www.coexistentia.cz/2018wybor/polacy2018.htm [dostęp: 30.01.2020]. 
Biorąc pod uwagę trzy gminy o najwyższym odsetku ludności deklarującej polską tożsamość narodową (Gródek, Koszarzyska, Milików), należy zauważyć, iż Coexistentia-Wspólnota cieszy się w nich względnie stabilnym poparciem na szczeblu wyborów samorządowych (gminnych) od 1994 roku. W tabeli 6 ujęto również osoby radnych z polskimi nazwiskami, wybranymi spoza list COEX. Należy jednak wyraźnie zaznaczyć, że nie przesądza to o ich identyfikacji narodowej, a jedynie pochodzeniu etnicznym. Warto zwrócić uwagę, że bardzo silną i stabilną liczebnie reprezentację od 1994 roku COEX posiada w gminie Milików (ok. 40\% głosów w radzie gminy).

Tabela 6

Polscy radni z ramienia Coexistentia—Wspólnota w wybranych gminach (1994—2018), cz. 1

\begin{tabular}{|c|c|c|c|c|c|c|c|c|}
\hline \multirow{2}{*}{$\begin{array}{l}\text { Miejscowość } \\
\text { (\% Polaków) }\end{array}$} & \multirow{2}{*}{ Polscy radni } & \multicolumn{7}{|c|}{ Rok wyborów samorządowych (gminnych) } \\
\hline & & 1994 & 1998 & 2002 & 2006 & 2010 & 2014 & 2018 \\
\hline \multirow{4}{*}{$\begin{array}{l}\text { Hrádek } \\
\text { Gródek }\end{array}$} & Liczba mandatów & 9 & 15 & 15 & 15 & 15 & 15 & 15 \\
\hline & COEX & 6 & 3 & 3 & 3 & 4 & 3 & 4 \\
\hline & $\begin{array}{l}\text { Pozostali z PL } \\
\text { nazwiskiem }\end{array}$ & 3 & 7 & 7 & 10 & 7 & 3 & 4 \\
\hline & $\%$ COEX & 66,7 & 20 & 20 & 20 & 26,7 & 20 & 26,7 \\
\hline \multirow{4}{*}{$\begin{array}{l}\text { Košařiska } \\
\text { Koszarzyska } \\
(27,9)\end{array}$} & Liczba mandatów & 7 & 9 & 9 & 9 & 9 & 9 & 9 \\
\hline & COEX & 2 & 3 & 2 & 1 & 1 & 2 & 2 \\
\hline & $\begin{array}{l}\text { Pozostali z PL } \\
\text { nazwiskiem }\end{array}$ & 3 & 3 & 4 & 2 & 3 & 2 & 1 \\
\hline & $\%$ COEX & 28,6 & 33,3 & 22,2 & 11,1 & 11,1 & 22,2 & 22,2 \\
\hline \multirow{4}{*}{$\begin{array}{l}\text { Milíkov } \\
\text { Milików } \\
(\mathbf{3 0 , 4 )}\end{array}$} & Liczba mandatów & 13 & 13 & 13 & 13 & 13 & 13 & 13 \\
\hline & COEX & 5 & 5 & 6 & 5 & 5 & 5 & 6 \\
\hline & $\begin{array}{l}\text { Pozostali z PL } \\
\text { nazwiskiem }\end{array}$ & 3 & 5 & 2 & 4 & 2 & 2 & 3 \\
\hline & $\%$ COEX & 38,5 & 38,5 & 46,2 & 38,5 & 38,5 & 38,5 & 46,2 \\
\hline
\end{tabular}

Źródło: opracowanie własne na podstawie: www.volby.cz [dostęp: 23.02.2021]; http://www.coexistentia.cz/2018wybor/polacy2018.htm [dostęp: 30.01.2020].

Dla porównania w tabeli 7 zaprezentowano wyniki poparcia dla COEX w pięciu innych gminach, w których w wyborach samorządowych w 2018 roku polscy kandydaci (także spoza list COEX) uzyskali poparcie powyżej 40\%. Tak wysokie poparcie było wówczas możliwe prawdopodobnie z tego powodu, że polscy kandydaci startowali z różnych list wyborczych, nierzadko też jako kandydaci niezależni. W niżej przedstawionych gminach jedynie w przypadku Wędryni można mówić o stabilnym i wysokim poparciu dla COEX, oscylującym podobnie jak w przypadku Milikowa na poziomie ok. $40 \%$. 
Polscy radni z ramienia Coexistentia-Wspólnota w wybranych gminach (1994-2018), cz. 2

\begin{tabular}{|c|c|c|c|c|c|c|c|c|}
\hline \multirow{2}{*}{$\begin{array}{l}\text { Miejscowość } \\
\text { (\% Polaków) }\end{array}$} & \multirow{2}{*}{ Polscy radni } & \multicolumn{7}{|c|}{ Rok wyborów samorządowych (gminnych) } \\
\hline & & 1994 & 1998 & 2002 & 2006 & 2010 & 2014 & 2018 \\
\hline \multirow{3}{*}{$\begin{array}{l}\text { Albrechtice } \\
\text { Olbrachcice } \\
(17,6)\end{array}$} & Liczba mandatów & 17 & 17 & 15 & 15 & 15 & 15 & 15 \\
\hline & COEX & 2 & 2 & 1 & 1 & 2 & 1 & 1 \\
\hline & $\% \mathrm{COEX}$ & 11,8 & 11,8 & 6,7 & 6,7 & 13,3 & 6,7 & 6,7 \\
\hline \multirow{3}{*}{$\begin{array}{l}\text { Písečná } \\
\text { Pioseczna } \\
(19,4)\end{array}$} & Liczba mandatów & $\mathrm{x}$ & $\mathrm{x}$ & 7 & 7 & 7 & 7 & 7 \\
\hline & COEX & $\mathrm{x}$ & $\mathrm{x}$ & 0 & 0 & 0 & 0 & 0 \\
\hline & $\%$ COEX & $\mathbf{x}$ & $\mathbf{x}$ & $\mathbf{0 , 0}$ & $\mathbf{0 , 0}$ & $\mathbf{0 , 0}$ & $\mathbf{0 , 0}$ & $\mathbf{0 , 0}$ \\
\hline \multirow{3}{*}{$\begin{array}{l}\text { Vendryně } \\
\text { Wędrynia } \\
(27,1)\end{array}$} & Liczba mandatów & $\mathrm{x}$ & 17 & 17 & 17 & 17 & 17 & 17 \\
\hline & COEX & $\mathrm{x}$ & 5 & 6 & 5 & 6 & 7 & 7 \\
\hline & $\% \mathrm{COEX}$ & $\mathbf{x}$ & 29,4 & 35,3 & 29,4 & 35,3 & 41,2 & 41,2 \\
\hline \multirow{3}{*}{$\begin{array}{l}\text { Dolní Lomná } \\
\text { Dolna Lomna } \\
(25,4)\end{array}$} & Liczba mandatów & 7 & 7 & 7 & 7 & 7 & 7 & 7 \\
\hline & COEX & 1 & 2 & 1 & 1 & 1 & 2 & 1 \\
\hline & $\% \mathrm{COEX}$ & 14,3 & 28,6 & 14,3 & 14,3 & 14,3 & 28,6 & 14,3 \\
\hline \multirow{3}{*}{$\begin{array}{l}\text { Stonava } \\
\text { Stonawa } \\
(19,0)\end{array}$} & Liczba mandatów & 7 & 7 & 7 & 7 & 7 & 7 & 7 \\
\hline & COEX & 1 & 1 & 1 & 1 & 0 & 0 & 0 \\
\hline & $\%$ COEX & 14,3 & 14,3 & 14,3 & 14,3 & $\mathbf{0 , 0}$ & $\mathbf{0 , 0}$ & $\mathbf{0 , 0}$ \\
\hline
\end{tabular}

Źródło: opracowanie własne na podstawie: www.volby.cz [dostęp: 23.02.2021]; http://www.coexistentia.cz/2018wybor/polacy2018.htm [30.01.2020].

Reasumując, aktywność Polaków w wymiarze wyborów samorządowych wykazuje się dużą dynamiką, przy czym ma ona dwojaki charakter: z jednej strony w ramach ugrupowania COEX, stanowiącego swego rodzaju namiastkę polskiej partii etnicznej, z drugiej — w ramach innych lokalnych ugrupowań. W ostatnich wyborach jedną trzecią wszystkich polskich radnych (tj. 39/105) stanowili reprezentanci COEX. Ogółem polscy radni stanowili w 2018 roku nieco ponad $15 \%$ ogółu radnych gminnych na Zaolziu, co odzwierciedla wielkość potencjału etnicznego polskiej mniejszości, choć w części gmin widać wyraźną nadreprezentację polskich radnych w stosunku do odsetka ludności polskiej mierzonego według spisów powszechnych.

\section{Wybory ogólnokrajowe (parlamentarne, prezydenckie) na Zaolziu (1990—2017)}

Mając na uwadze aktywność polityczną, a ściślej wyborczą Polaków mieszkających na Zaolziu w wyborach ogólnokrajowych, w odniesieniu do okresu po 1989 roku, należy odnotować kilka istotnych wydarzeń i procesów. 
Po pierwsze — jedynie w okresie 1992-1996 mniejszość polska nie posiadała w czeskim parlamencie (Izba Poselska, Senat) swojej reprezentacji. W latach 1990 - 1992 aż trzech Polaków zasiadało w Izbie Ludowej Zgromadzenia Federalnego, jeden zaś - w Czeskiej Radzie Narodowej. Była to rekordowa reprezentacja od początków istnienia czechosłowackiego parlamentu (tj. od 1918 roku). Trzeba przy tym zaznaczyć, że ówczesne ordynacje wyborcze nie przewidywały jakichkolwiek koncesji na rzecz mniejszości narodowych i etnicznych. (Przeciwnie, tak projektowano okręgi wyborcze, aby przedstawicielom nieczeskiej grupy narodowej zmniejszać szanse na objęcie funkcji posła lub senatora). W omawianym okresie zarysowały się też dwa nurty polityczne wśród Polaków: liberalny związany z Forum Obywatelskim i konserwatywny zorientowany na prawa mniejszości, związany z ruchem Coexistentia. Z kolei od wyborów w 1996 roku, w latach 1996-2017, polska mniejszość miała trzech reprezentantów w Izbie Poselskiej Republiki Czeskiej, przy czym wszyscy trzej urzędowali niepełną kadencję. W pierwszym przypadku (Wawrzyniec Fójcik) stało się tak $\mathrm{z}$ uwagi na przedterminowe wybory rozpisane w 1998 roku, w drugim przypadku (Marian Bielesz) z uwagi na zrzeczenie się mandatu poselskiego, $\mathrm{w}$ trzecim zaś (Jiří Rusnok) - z uwagi na skróconą kadencję parlamentu.

Po drugie - pomyślne dla Polaków z Zaolzia, mimo niezbyt sprzyjającego podziału Zaolzia na trzy okręgi wyborcze, okazały się wybory do Senatu, albowiem trzech kandydatów deklarujących się jako Polacy lub przyznający się otwarcie do polskich korzeni uzyskalo $w$ wyborach mandat senatorski (Andrzej Feber w 2000 r., Eduard Matykiewicz w 2002 r, Jiř́i Cieńciała w 2016 r.). Niewiele (głosów) brakowało, aby do tego grona w 2010 roku dołączył Stanisław Czudek. Co ciekawe, ani jeden z polskich parlamentarzystów nie dostał się do parlamentu z list dwóch - najczęściej popieranych przez Polaków partii, tj. ČSSD i KDU-ČSL (zob. tab. 8). 
Tabela 8

Reprezentanci polskiej mniejszości narodowej w czechosłowackim/czeskim parlamencie

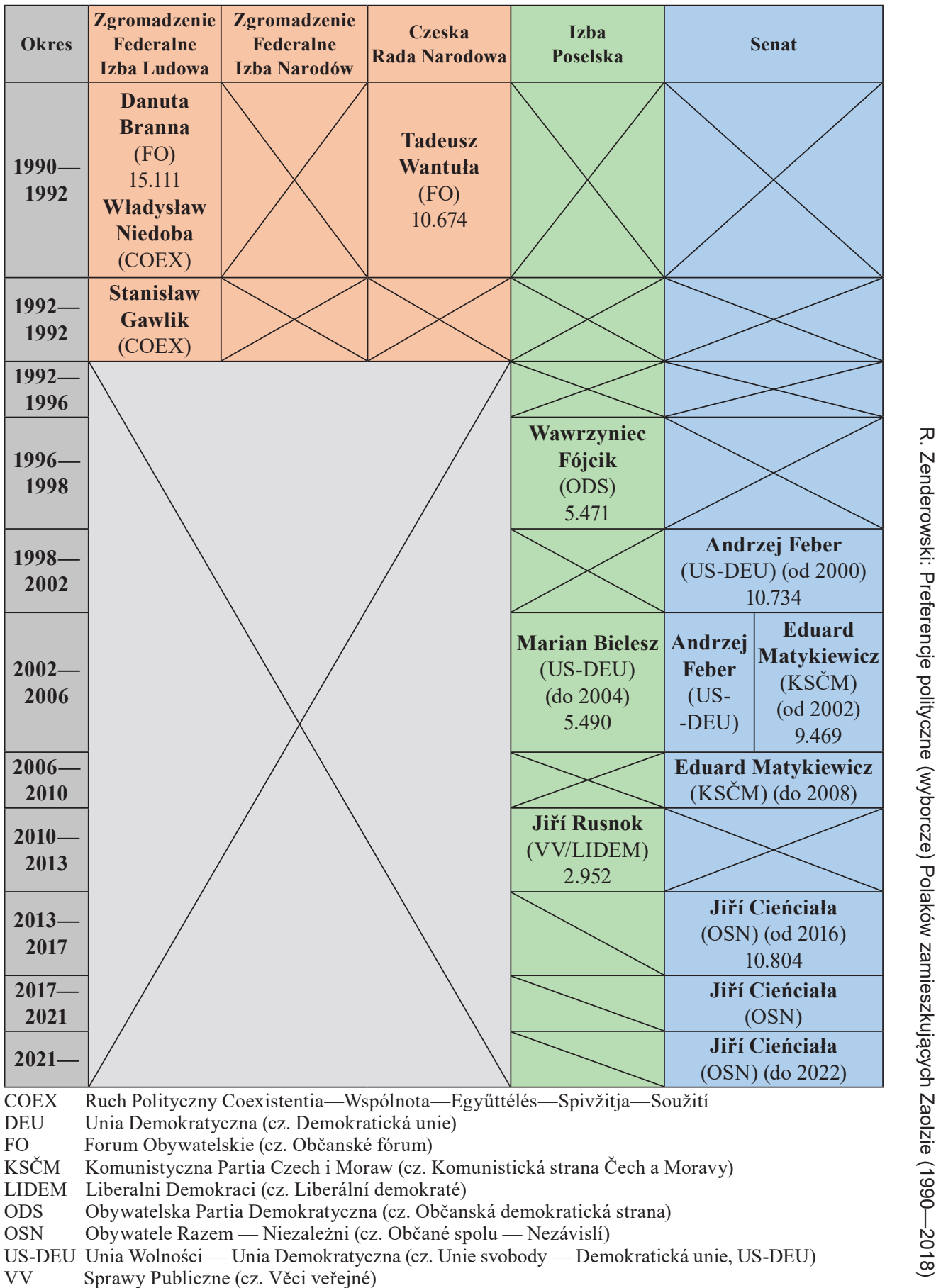

Przy nazwisku podano listę partyjną — wyborczą oraz uzyskaną liczbę głosów; BR — brak reprezentacji Źródło: opracowanie własne na podstawie: www.volby.cz [dostęp: 23.02.2021]. 
Po trzecie - w odróżnieniu od wcześniej wspomnianych wyborów, wybory prezydenckie właściwie nie miały większego znaczenia dla sytuacji (i reprezentacji) Polaków zamieszkujących Zaolzie, choć widać było wyraźnie wyższe poparcie, jakie uzyskał „krajan” Jiří Drahoš (pochodzący z Zaolzia, z mieszanej polsko-czeskiej rodziny) w gminach o znaczącym odsetku ludności polskiej (zob. rys. 3).

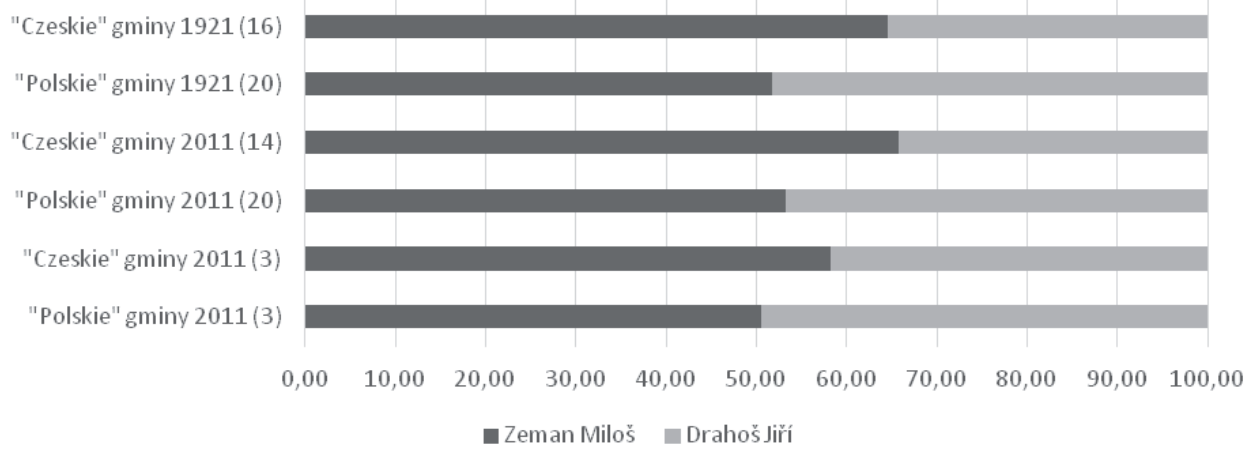

Rys. 3. Wyniki wyborów na urząd Prezydenta Republiki Czeskiej w „polskich” i „czeskich” gminach na Zaolziu (II tura, 2018 r., w \%)

Źródło: opracowanie własne na podstawie: Český statistický úřad: Volby.cz. https://volby.cz [dostęp: 23.02.2021].

Po czwarte - wyniki zwłaszcza wyborów parlamentarnych pozwalają wyodrębnić dwa subregiony: północny (pokrywający się z zakresem terytorialnym powiatu Karwina), zdominowany przez wyborców partii lewicowych lub centro-lewicowych (KSČM, ČSSD), oraz południowy (wschodnia część powiatu Frydek-Mistek), w którym obok centrolewicowej ČSSD zdecydowanie większym poparciem niż na północy regionu cieszy się chadecka KDU-ČSL. Gdy się porówna te preferencje wyborcze z wynikami wyborów z okresu międzywojennego (1925, 1929, 1935), bardzo wyraźnie widać, że mimo upływu czasu pewne wzorce zachowań politycznych pozostają niezmienne. Tereny, gdzie niegdyś bezapelacyjnie zwyciężały Komunistyczna Partia Czechosłowacji i Polska Socjalistyczna Partia Robotnicza (powiaty sądowe: Frysztat i Bogumin), zostały „zagospodarowane” przez Komunistyczną Partię Czech i Moraw oraz Czeską Partię Socjaldemokratyczną. Tam, gdzie przed II wojną światową zwyciężały (w różnych konfiguracjach koalicyjnych) chadecki Związek Śląskich Katolików w Czechosłowacji (zdominowany przez polskich katolików) oraz chadecko-ludowe Stronnictwo Ludowe w Czechosłowacji (zdominowane przez polskich ewangelików) i socjaldemo¡ kratyczna Polska Socjalistyczna Partia Robotnicza, widać wyraźną przewagę sympatii politycznych skierowanych w stronę KDU-ČSL oraz ČSSD (zob. rys. 4, 5,6 ). W tym układzie ČSSD jawić się może jako swego rodzaju „partia środka”, ciesząca się porównywalnym poparciem wyborczym w północnej i południowej części Zaolzia, choć w ostatnich latach jej poparcie słabnie na rzecz populistycznej partii ANO. 


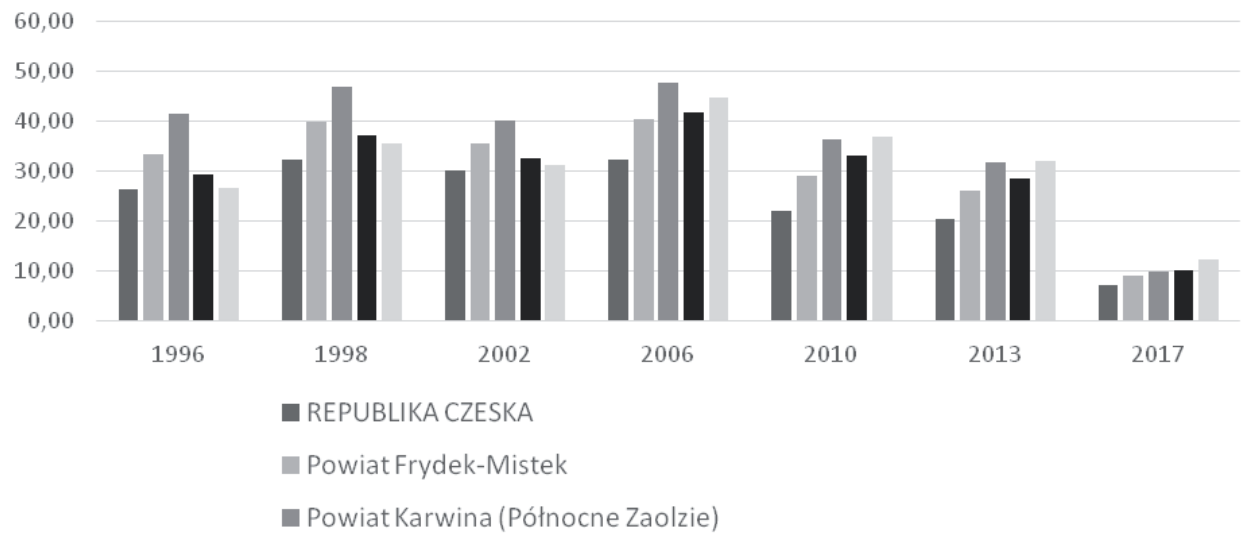

- Południowe Zaolzie (wsch. część powiatu FM) bez Trzyńca

Góralszczyzna

Rys. 4. Poparcie dla ČSSD w wyborach w latach 1996-2017 na Zaolziu (w \%)

Źródło: opracowanie własne na podstawie: Český statistický úrad: Volby.cz. https://volby.cz [dostęp: 23.02.2021].

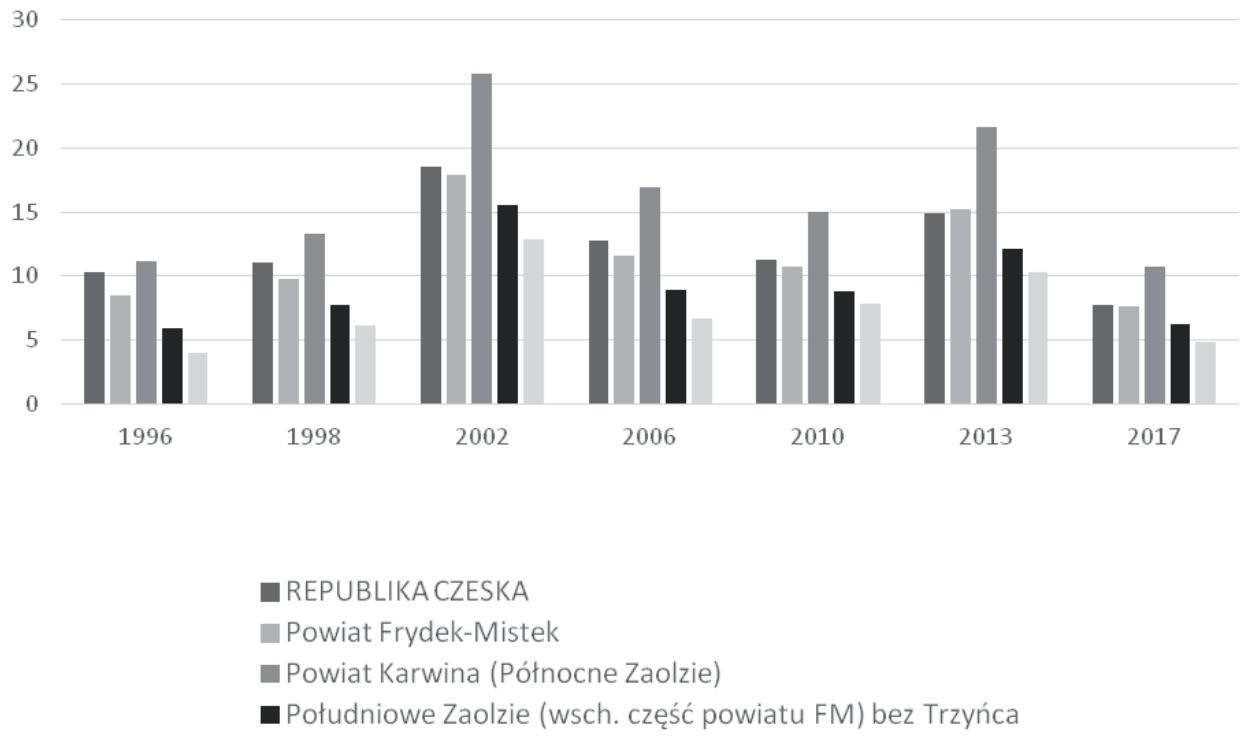

Rys. 5. Poparcie dla KSČM w wyborach w latach 1996-2017 na Zaolziu (w \%)

Źródło: opracowanie własne na podstawie: Český statistický úřad: Volby.cz. https://volby.cz [dostęp: 23.02.2021]. 


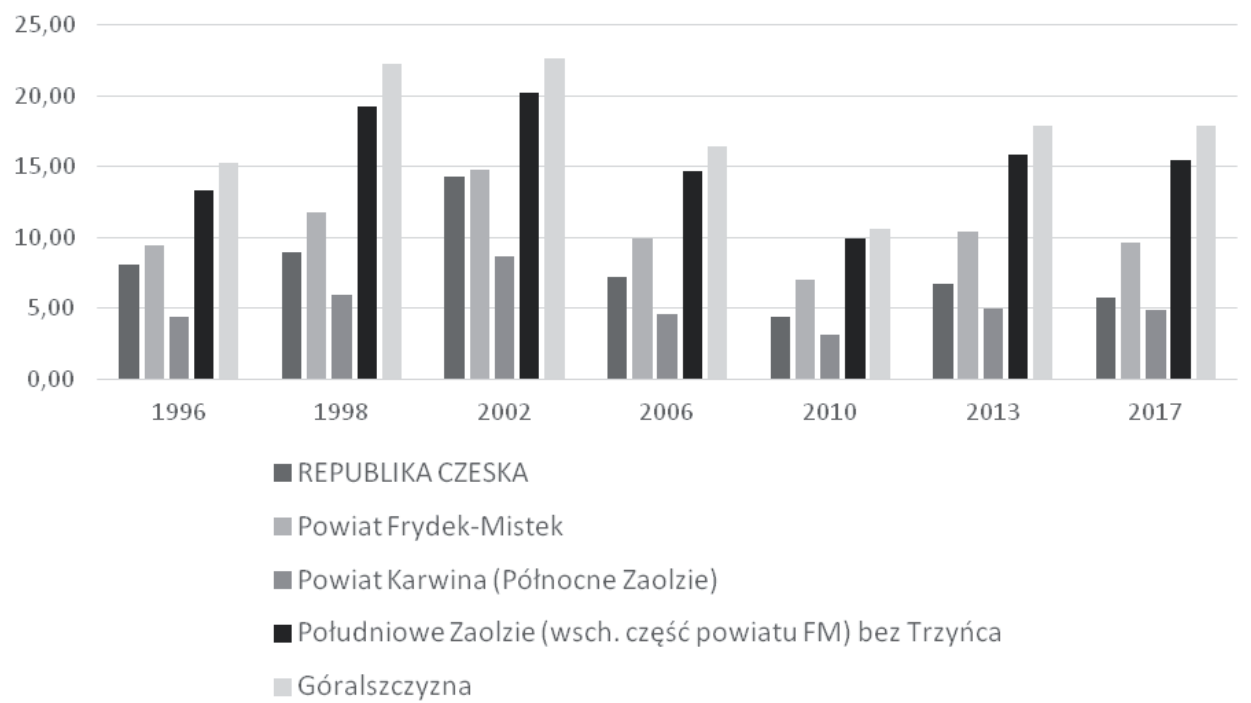

Rys. 6. Poparcie dla KDU-ČSL w wyborach w latach 1996-2017 na Zaolziu (w \%)

Źródło: opracowanie własne na podstawie: Český statistický úřad: Volby.cz. https://volby.cz [dostęp: 23.02.2021].

Po piąte - co już kilkakrotnie odnotowano, analizując szczegółowo wyniki poparcia dla poszczególnych partii politycznych — mieszkańcy gmin, w których ludność polska stanowi liczący się odsetek mieszkańców, mają większą skłonność do głosowania na partie konserwatywne (zwłaszcza KDU-ČSL) (Český statistický úřad: Odbor statistiky obyvatelstva..., s. 14), z kolei mieszkańcy gmin o znikomym odsetku Polaków chętniej wybierają partie lewicowe (zwłaszcza KSČM) (zob. rys. 7, 8). Może mieć to związek z deklarowaną religijnością, która w polskiej społeczności jest zdecydowanie wyższa niż w czeskim społeczeństwie oraz zdecydowanie wyższa w południowej niż w północnej części Zaolzia. Warto zauważyć, że spośród wszystkich grup narodowościowych zamieszkujących Republikę Czeską to właśnie Polacy znajdują się na czele listy najbardziej wierzących. W 2011 roku w skali kraju jako osoby wierzące zadeklarowało się 20,8\% mieszkańców kraju, przy czym najbardziej religijną grupą okazali się Polacy (56,9\%), następnie Ślązacy (47,4\%) i Słowacy $(40,2 \%)$, najmniej religijną zaś - Wietnamczycy $(8,7 \%)$ i Czesi $(22,6 \%)$. Poza tym warto zwrócić uwagę na różnice między północną a południową częścią Zaolzia jeśli chodzi o religijność. Są one bardzo wyraziste. Wystarczy porównać ze sobą odsetek osób religijnych w gminie Orłowa $(12,3 \%)$ z jednej strony i w gminie Jabłonków $(51,8 \%)$ z drugiej (Český statistický úr̆ad: Sčitání lidu, domů a bytů 2011...) (zob. tab. 9). Wiele wskazuje zatem na to, że religijność stanowi istotną zmienną niezależną determinującą wybory polityczne mieszkańców Zaolzia. 
Religijność na Zaolziu w gminach o rozszerzonych kompetencjach (obcí s rozšířenou působností) w $2011 \mathrm{r}$.

\begin{tabular}{|l|c|c|c|c|c|c|c|}
\hline \multirow{2}{*}{ Religia/gmina } & Jablunkov & Třinec & Český Těśín & Karviná & Havířov & Orlová & Bohumín \\
\cline { 2 - 8 } & Jabłonków & Trzyniec & Cz.Cieszyn & Karwina & Hawierzów & Orlowa & Bogumin \\
\hline \multirow{2}{*}{$\begin{array}{l}\text { Ogółem } \\
\text { mieszkańców }\end{array}$} & 22214 & 54627 & 25516 & 68024 & 91092 & 43020 & 28742 \\
\cline { 2 - 9 } & $100 \%$ & $100 \%$ & $100 \%$ & $100 \%$ & $100 \%$ & $100 \%$ & $100 \%$ \\
\hline \multirow{2}{*}{ Osoby religijne } & 11505 & 18849 & 8185 & 11388 & 13808 & 5294 & 4111 \\
\cline { 2 - 9 } & $51,8 \%$ & $34,5 \%$ & $32,1 \%$ & $16,7 \%$ & $15,2 \%$ & $12,3 \%$ & $14,3 \%$ \\
\hline \multirow{2}{*}{ Osoby niereligijne } & 1945 & 9230 & 5457 & 20705 & 32398 & 15271 & 9101 \\
\cline { 2 - 8 } & $8,8 \%$ & $16,9 \%$ & $21,4 \%$ & $30,4 \%$ & $35,6 \%$ & $35,5 \%$ & $31,7 \%$ \\
\hline \multirow{2}{*}{ Nie ustalono } & 7556 & 21991 & 9933 & 30673 & 37891 & 19487 & 13362 \\
\cline { 2 - 8 } & $34,0 \%$ & $40,3 \%$ & $38,9 \%$ & $45,1 \%$ & $41,6 \%$ & $45,3 \%$ & $46,5 \%$ \\
\hline
\end{tabular}

Źródło: opracowanie własne na podstawie: Český statistický úřad: Sčitání lidu, domů a bytů 2011, Obyvatelstvo podle náboženské víry a podle velikostnich skupin obci, okresů a správnich obvodů ORP — Moravskoslezský kraj. https://www.czso.cz [dostęp: 17.02.2020].

Po szóste - trudno wyprowadzić wniosek o jakimś znaczącym osłabnięciu aktywności politycznej Polaków, które postępowałoby wraz ze spadkiem liczebności polskiej mniejszości na Zaolziu. Polacy, w tym polscy wyborcy, tworzą względnie zintegrowaną i świadomą swojej podmiotowości wspólnotę, której przedstawiciele dobrze rozumieją zarówno mechanizmy wyborcze, jak i zasady reprezentacji politycznej. Polacy wydają się też bardziej zdeterminowani do aktywności politycznej, na ogół na szczeblu lokalnym, czego efektem jest w wielu przypadkach „nadreprezentacja” Polaków w radach gmin (w stosunku do ich liczebności w gminie).

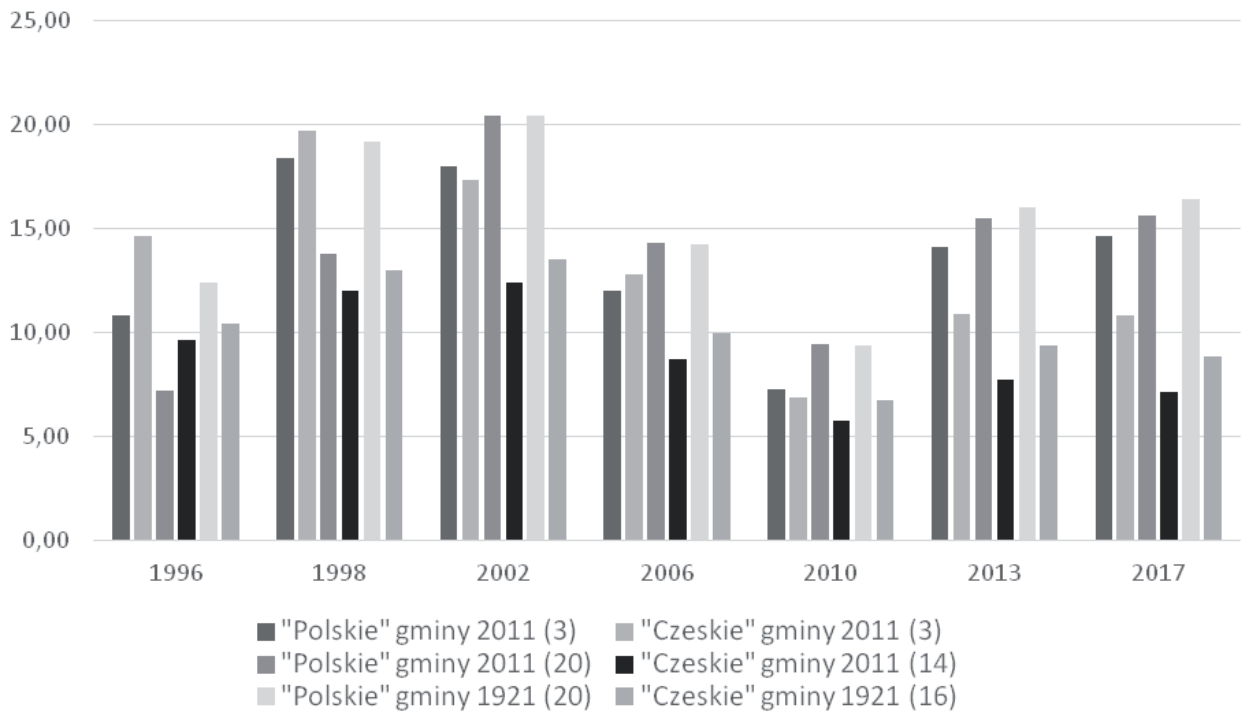

Rys. 7. Poparcie dla KDU-ČSL w wyborach w latach 1996-2017 w „polskich” i „,czeskich” gminach na Zaolziu (w \%) 


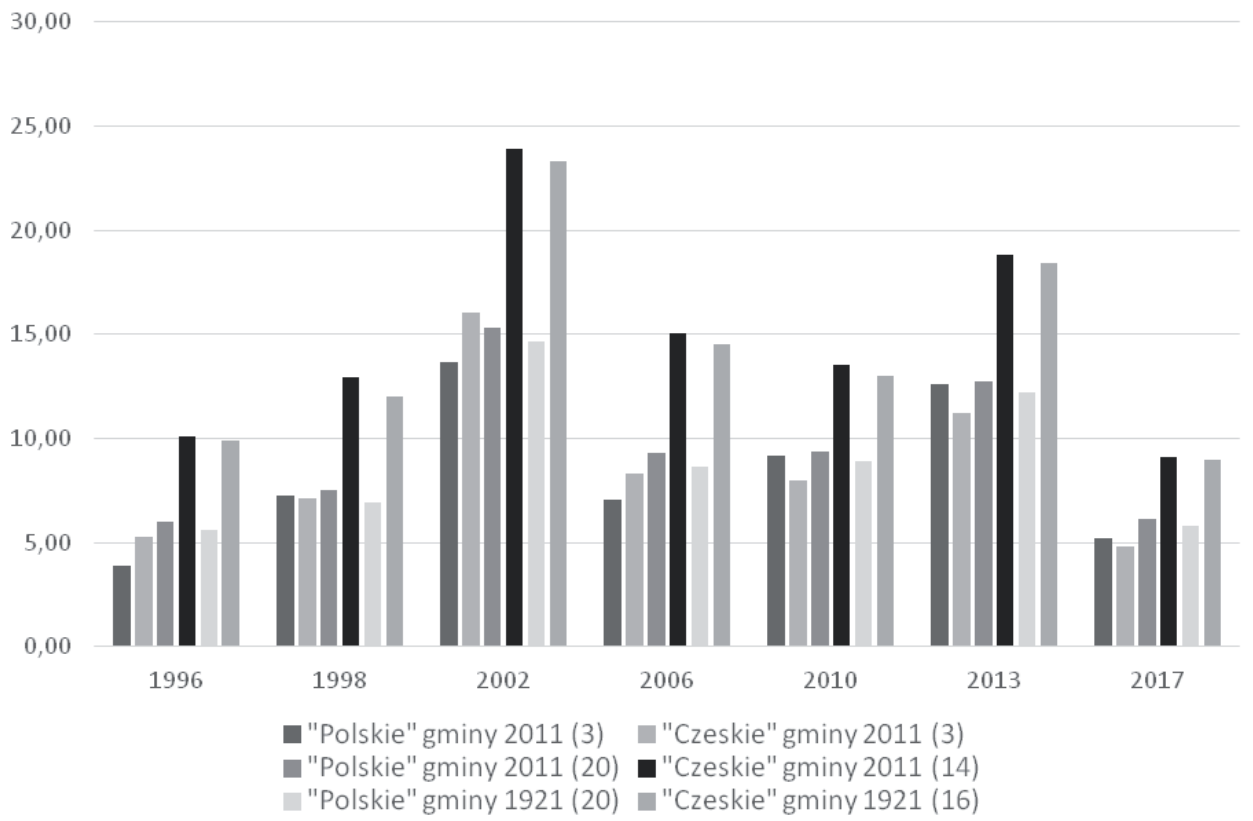

Rys. 8. Poparcie dla KSČM w wyborach w latach 1996-2017 w „polskich” i „,czeskich” gminach na Zaolziu (w \%)

Źródło: opracowanie własne na podstawie: Český statistický úrad: Volby.cz. https://volby.cz [dostęp: 23.02.2021].

\section{Konkluzje}

Zaolziańscy Polacy nie mają jednej strategii pozyskiwania poparcia wyborczego ani budowania zaplecza politycznego. Bardzo wyraźnie zaznacza się podział na zwolenników forsowania polskich interesów pod szyldem ugrupowań artykułujących interesy mniejszości (zwłaszcza COEX) oraz na zwolenników wchodzenia w struktury czeskich ugrupowań politycznych i uzyskiwania tym sposobem pewnych koncesji na rzecz polskiej mniejszości. W pewnym uproszczeniu można byłoby obydwa modele zachowań politycznych określić jako (w kolejności): konfrontacyjny i kooperacyjny. $Z$ powyższego trudno jednak wyprowadzić wniosek o jakimś , politycznym niezgraniu” Polaków zamieszkujących Zaolzie. Przeciwnie, można postawić tezę, że taka taktyka wyborcza, choć zapewne niekoordynowana przez jakiś ośrodek decyzyjny, przynosi w sumie polskiej mniejszości wymierne korzyści polityczne. Ani bowiem całkowite zamknięcie się w getcie etnicznym, ani wybór opcji aktywności politycznej w ramach ogólnoczeskich ugrupowań politycznych nie stwarzałoby dla polskiej mniejszości wystarczających szans i okazji do realizacji swoich interesów politycznych. Paradoksalnie zatem owa dwutorowość działań politycznych podejmowanych przez Polaków mieszkających na Zaolziu 
wydaje się racjonalną strategią polityczną. Zważywszy jednak na trwałe tendencje demograficzne, tj. systematyczny spadek odsetka osób deklarujących narodowość polską (na Zaolziu), w przyszłości należy spodziewać się stopniowego zaniku pierwszej z wymienionych strategii wyborczych, a jednocześnie utrwalania się strategii polegającej na włączaniu się w struktury dużych ugrupowań politycznych o zasięgu ogólnokrajowym. Niewykluczone też, że wywodzący się z polskiej grupy narodowościowej politycy częściej deklarować będą się nie jako Polacy, ale jako Czesi polskiego pochodzenia.

Wyniki niniejszych badań traktować należy wciąż jedynie w kategoriach hipotez wymagających zbadania. Z racji nieistnienia „czysto” polskich okręgów wyborczych i niemożności ustalenia w drodze analizy statystycznej liczby głosów oddanych wyłącznie przez Polaków stanowią one punkt wyjścia do dalszych analiz, w wymiarze badań zarówno ilościowych (np. ankietowych wśród osób deklarujących polską narodowość), jak i jakościowych (np. w postaci wywiadów pogłębionych z liderami lokalnych społeczności).

\section{Bibliografia}

Borák M., Gawrecki J., red., 1992: Nástin dějin Těšinska. Ostrava-Praha: Advertis Ostrava.

Český statistický úřad: Odbor statistiky obyvatelstva, Náboženská víra obyvatel podle výsledku Sčítání lidu. Praha 2014.

Český statistický úr̆ad: Sčitání lidu, domů a bytů 2011, Obyvatelstvo podle náboženské viry a podle velikostnich skupin obcí, okresủ a správních obvodů ORP - Moravskoslezský kraj. https://www.czso.cz [dostęp: 17.02.2020].

Český statistický úřad: Sčítání lidu, domů a bytů. https://www.czso.cz/csu/czso/scitanilidu-domu-a-bytu [dostęp: 23.02.2021].

Český statistický úřad: Volby.cz. https://volby.cz [dostęp: 23.02.2021].

De Winter L., Türsan H., 2003: Regionalist Parties in Western Europe. New York: Routledge.

Hannan K., 1996a: Borders of Language and Identity in Teschen Silesia. New York: Peter Lang.

Hannan K., 1996b: Identity and Assimilation among the Poles of Zaolzie. "The Sarmatian Review", No 1.

Hannan K., 1999: Language and Ethnicity among Students in Teschen Silesia. "Nationalities Papers", Vol. 27, No. 2, s. 191-203.

Hannan K., 2005: Polishness in the Borderlands. W: Burszta, T. Kamusella, S. Wojciechowski, Nationalisms Across the Globe (Vol I: Europe), Poznań: School of Humanities and Journalism, s. 205-226.

Herbut R., 2002: Teoria i praktyka funkcjonowania partii politycznych. Wrocław: Wydawnictwo Uniwersytetu Wrocławskiego.

Horovitz D.L., 1985: Ethnic Groups in Conflict. Berkeley: University of California Press. 
Ishiyama J., 2001: Ethnopolitical Parties and Democratic Consolidation in Postcommunist Eastern Europe. "Nationalism \& Ethnic Politics", Vol. 7(3), s. 25-45.

Ishiyama J., Breuning M., 2011: What is in a Name? Ethnic Party Identity and Democratic Development in Post-Communist Politics. "Party Politics", Vol. 17(2), s. 223-241.

Kopeček L., 2002: Study of Interest Representation Development of Polish Minority in the Czech Republic. "Středoevropské politické studie - Central European Political Studies Review”, nr 4. https://journals.muni.cz/cepsr/article/view/3918/5357 [dostęp: 23.10.2019].

Kopeček L., 2003: Coexistentia-Soužití a politická reprezentace polské menšiny na Těšinsku. "Středoevropské politické studie — Central European Political Studies Review", nr 5. https://journals.muni.cz/cepsr/article/view/3941/5312 [dostęp: 23.10.2019].

Lipset S.M., Rokkan S., 1967: Party Systems and Voters: Cross-National Perspectives. New York: Free Press.

Mareš M., 2003: Etnické a regionální subjekty ve stranickém systému České republiky. "Středoevropské politické studie - Central European Political Studies Review", nr 5. https://journals.muni.cz/cepsr/article/view/3939/5310 [dostęp: 15.04.2021].

Mareš M., Kopeček L., Pečínka P., Stýskalíková V., 2004: Etnické menšiny a česká politika. Analýza stranických př́stupủ k etnické a imigrační politice po roce 1989. Brno: Centrum pro studium demokracie a kultury.

Mareš M., red., 2003: Etnické a regionální strany v ČR po roce 1989. Brno: Centrum pro studium demokracie a kultury.

Mareš M., Strmiska M., 2006: Political Participation by Ethnic Minorities in the Czech Republic. W: T. Sirovátka: The Challenge of Social Inclusion: Minorities and Marginalised Groups in Czech Society. Brno: Společnost pro odbornou literaturu — Barrister \& Principal, s. 267-289.

Polacy $w$ radach miast i gmin (2018-2022 r.) / Poláci v zastupitelstvech měst a obcí (2018-2022). http://www.coexistentia.cz/2018wybor/polacy2018.htm [dostęp: 30.01.2020].

Szelong K.: Zaolzie. Pojęcie, obszar i historia. https://openairmuseum.info/pl/dzialy/Zaolzie/Pojecie-obszar-i-historia [dostęp: 22.10.2019].

Touquet H., 2011: Multi-Ethnic Parties in Bosnia-Herzegovina: Naša Stranka and the Paradoxes of Postethnic Politics. "Studies in Ethnicity and Nationalism", Vol. 11(3), s. $451-467$.

Van Cott D.L., 2005: From Movements to Parties in Latin America: The Evolution of Ethnic Politics. New York: Cambridge University Press.

Wasiuta M., 2017: Partie etniczne w Republice Czeskiej. „Sprawy Narodowościowe. Seria Nowa / Nationalities Affairs. New Series", nr 49, s. 1-19.

Witt K., 1935: Die Teschener Frage. Berlin: Volk und Reich Verlag.

Woźnica R., 2016: Partie polityczne i udział mniejszości w życiu politycznym Macedonii i Bułgarii. „Studia Środkowoeuropejskie i Bałkanistyczne”, t. XXIV, s. 187-198.

Wójcicki M., 2014: Pojęcie, istota i formy partycypacji społecznej w procesie planowania przestrzennego. „Rozwój Regionalny i Polityka Regionalna”, t. 24, s. 169-183.

Zenderowski R., 2020: The Election Attitudes Among the Polish Minority Inhabiting the Region of Zaolzie in the Czech Republic (1990-2018). "Codrul Cosminului", Vol. 1, s. 113 -142. https://doi.org/10.4316/CC.2020.01.008. 